BARRY P. BOSWORTH

Brookings Institution

\title{
Capital Formation and Economic Policy
}

THE CURRENT DISCUSSION of capital formation in the United States reflects a general belief that investment has been inadequate during the 1970s and that this shortfall explains a large part of the current economic difficulties. The productivity slowdown, in particular, is often blamed on the failure of investment to keep the capital stock growing as fast as the number of workers.

Specific conclusions about the "capital scarcity problem" in the United States and many of the policy measures offered to solve it are often derived from a neoclassical model of an economy operating close to full employment. The economy is also viewed as moving along a competitive equilibrium growth path in the sense that the returns to factors of production measure their contribution to output. At full employment the analysis of capital formation quite properly emphasizes allocative issues, such as the choice between current and future consumption (saving) and the distribution of private saving among competing uses (home building, business investment, and government deficits). Most important, the model assigns relative prices a primary role in the allocation of resources among industries and over time: resources flow where returns are highest, and the rate of interest determines intertemporal consumption decisions.

Using such a model, some commentators have attributed an alleged

I benefited from comments of Henry J. Aaron, Edward F. Denison, Charles L. Schultze, and members of the Brookings Panel. Kathleen Elliott Yinug prepared the manuscript. 
capital scarcity to excessive taxation of capital income. ${ }^{1}$ According to that view, inflation has substantially raised effective tax rates and lowered after-tax private return to capital. The result, it is asserted, has been reduced saving and investment, and this slowdown in investment has reduced the growth of output per worker.

These perceptions have had an enormous impact on economic policy. The expansion of private business investment has become a prominent goal, and economists have rushed forth with competing proposals on how to stimulate both saving and investment.

Yet, in several respects the actual course of capital formation during the 1970s contradicts the story being told by the neoclassical model. Table 1 illustrates the confusion that exists even in deciding whether capital formation has slowed. Those who argue that it has not point frequently to the ratio of gross investment to gross domestic business output. Whether measured in current or constant dollars, the ratio shown in the first two rows has increased, not fallen, during the 1970s. On the other hand, some commentators emphasize that net investment (gross investment minus depreciation) has declined as a share of current output. Net investment, however, should be compared with net output (gross output minus depreciation), as shown in the next two rows of the table. On that basis the puzzle is not why net investment has been so low in the 1970s, but why it was so high during the last half of the 1960s.

For evaluating the growth in potential output the more relevant measure is the growth of the capital stock, shown in the fifth row, rather than net investment, and there is evidence of a decline to pre-1960s growth rates on that basis. Capital growth appears weakest when gauged by growth in the capital-labor ratio, shown in the next two rows, as the expansion of the capital stock failed to keep pace with the rapid growth of employment during the 1970s. The actual change in the capital-labor ratio, however, is very sensitive to business cycle fluctuations and the slowdown is less pronounced on a cyclically adjusted basis. On the other hand, the capital-output ratio, shown in the last row, rose substantially throughout that decade, indicating that the growth of the capital stock exceeded that of output. Thus the range of possible answers seems, on

1. There is a large literature on this subject, but the policy aspects are addressed in a nontechnical fashion in Martin Feldstein, "Inflation and the American Economy," Public Interest, no. 67 (Spring 1982), pp. 63-76. 
Table 1. Alternative Measures of the Trend in Capital Formation of the Domestic Nonresidential Business Sector, Selected Periods, 1951-80 ${ }^{a}$

\begin{tabular}{|c|c|c|c|c|c|c|}
\hline Measure & $\begin{array}{c}1951- \\
55\end{array}$ & $\begin{array}{c}1956- \\
60\end{array}$ & $\begin{array}{c}1961- \\
65\end{array}$ & $\begin{array}{c}1966- \\
70\end{array}$ & $\begin{array}{c}1971- \\
75\end{array}$ & $\begin{array}{c}1976- \\
80\end{array}$ \\
\hline \multicolumn{7}{|c|}{$\begin{array}{l}\text { Gross fixed nonresidential invest- } \\
\text { ment as a percent of gross out- } \\
\text { put }\end{array}$} \\
\hline Current dollars & 11.4 & 12.2 & 12.1 & 13.6 & 13.7 & 14.6 \\
\hline Constant dollars & 11.7 & 11.9 & 12.3 & 13.9 & 13.6 & 14.5 \\
\hline \multicolumn{7}{|c|}{$\begin{array}{l}\text { Net fixed nonresidential investment } \\
\text { as a percent of net output }\end{array}$} \\
\hline Current dollars & 3.8 & 3.5 & 4.0 & 5.6 & 4.4 & 4.3 \\
\hline Constant dollars & 3.9 & 3.5 & 4.2 & 5.8 & 4.5 & 4.3 \\
\hline $\begin{array}{l}\text { Net fixed nonresidentia } \\
\text { as a percent of net } \\
\text { stock }^{\text {b }}\end{array}$ & 4.1 & 3.5 & 4.2 & 5.7 & 4.0 & 3.8 \\
\hline \multicolumn{7}{|c|}{$\begin{array}{l}\text { Percentage change in the ratio of net } \\
\text { capital stock to total business } \\
\text { hours }^{b}\end{array}$} \\
\hline Actual & 3.3 & 3.5 & 2.9 & 4.3 & 3.2 & 0.6 \\
\hline Cyclically adjusted $^{c}$ & 3.4 & 3.1 & 4.0 & 3.9 & 2.8 & 1.3 \\
\hline $\begin{array}{l}\text { Ratio of net capital stoc } \\
\text { output }^{\mathrm{b}}\end{array}$ & 1.26 & 1.32 & 1.29 & 1.29 & 1.39 & 1.43 \\
\hline
\end{tabular}

Source: National income and product accounts and the U.S. Bureau of Labor Statistics.

a. Private business sector, excluding housing.

b. Both nonresidential stock of equipment and structures and output valued in 1972 dollars.

c. The cyclically adjusted series was derived from a regression of the change in the ratio of capital to man-hours on a time trend, the change in real GNP, and the utilization of potential GNP. The series represents the ratio adjusted for departures of GNP from potential. The procedure is the same as that used in figure 3 .

the surface, able to support any point of view as to the adequacy of past capital formation.

In this paper several issues relating to past trends in capital formation are examined in greater detail. First, the growth of capital has not slowed significantly and cannot explain more than a trivial part of the productivity slowdown, unless one wants to go beyond the model and argue that an extraordinary set of economic events has caused an unforeseen wave of capital obsolescence. The first objective of this paper is to document that assertion.

The second objective is to highlight the difficulty of using a simple neoclassical model to reconcile four observations. The first two are not hard to accommodate within the model: the growth in labor productivity (the output-labor ratio) has almost halted, and the growth of the capital- 
labor ratio has slowed sharply. These facts seem to tell a story of underinvestment. But the other two observations shatter this simple tale: the capital-output ratio has been very high by historical standards, and the rate of return on capital has plummeted.

The slow growth of labor productivity and the capital-labor ratio are both consistent with the argument that the combination of accelerated growth in the labor force during the 1970s and increased taxation of capital income limited the substitution of capital for labor in production. But according to that explanation of a relative scarcity of capital, the return on capital before taxes should have increased rather than fallen, and the capital-output ratio should have fallen rather than risen.

Alternatively, a rising capital-output ratio and a falling rate of return could be explained if an inflation-induced decline in the real cost of funds to firms had encouraged them to exploit more marginal investment projects.

I try to resolve these seemingly contradictory trends below. I first examine the role of capital formation in the slowdown of labor productivity. I then evaluate the hypothesis that the official estimates of the capital stock were too high during the 1970s because of an accelerated rate of obsolescence.

Trends in the before-tax return of capital are examined next. Even after adjustment for cyclical factors, there appears to have been a very sharp decline that began in the late 1960s and that has persisted to the present-lowering the before-tax rate of return from 11 percent in 1967 to 8 percent in 1980 . At the same time, the ratio of business tangible assets (plant, equipment, inventories, and land) to output, which had a slight downward trend in previous decades, rose substantially throughout the 1970s. On this basis alone, the decade appears to be one of a capital boom as business firms exploited more marginal projects, with a resulting drop in the average rate of return.

A decline in the before-tax return on capital could be explained by lower rates of capital taxation. Accordingly, I review the available evidence on effective tax rates for both the corporate and personal tax systems. Although there may be a basis for believing that some recent studies have exaggerated the extent of the increase in the effective tax on capital, there is little reason for believing that the tax declined. To that extent the observed fall in the before-tax rate of return is even more puzzling. 
I then pursue the issue further by asking whether the fall in the return on capital could be a reflection of a decline in the cost of funds to firms. Much of the analysis of capital formation and the effects of tax policy on investment incentives has assumed, either implicitly or explicitly, that the after-tax real rate of interest is unaffected by inflation. The primary effect of inflation is then to reduce investment incentives by increasing effective tax rates, thereby raising the required before-tax return. Nominal interest rates are expected to rise by more than the increment to expected inflation-the Fisher effect-so as to leave real after-tax rates of interest unchanged.

Certainly on an ex post basis nominal interest rates did not rise as the Fisher effect predicts. Many economists have emphasized the importance of distinguishing between expected and actual inflation; yet despite numerous attempts, existing studies conclude that inflation expectations (measured by a variety of different methods) were not fully reflected in nominal interest rates and that inflation has pushed down the cost of funds by more than the increase in taxes raised it. Some of the attempts to account for this within the neoclassical model by means of shifts in saving and investment schedules are inconsistent with the observed stability of saving and investment rates over the decade.

Finally, current economic policies have emphasized expanded tax incentives for both saving and business investment, a prescription based on the neoclassical model, along with a restrictive monetary policy to reduce home building and consumer durable expenditures. The final objective of this paper is to evaluate this policy combination.

\section{Capital and Productivity Growth}

The interpretation of recent trends in capital formation and the role of those trends in explaining the slowdown in productivity growth and associated economic problems are intimately bound up in the issues of how to measure the capital stock and the flow of services from it. Economists believe that they have fairly accurate data on the dollar amount of new capital formation, but know much less about the actual flow of services currently provided by that capital. The construction of an index of capital services, comparable to information on the hours worked by labor, involves severe measurement problems; and measuring 
quality change in the services of capital may be even more difficult than constructing an index of labor inputs.

Measurement issues are responsible for the significant divergences in the conclusions of major growth-accounting studies that have examined the role of capital. A recent article in BPEA by Norsworthy, Harper, and Kunze concluded that slower capital accumulation accounted for most of the slowdown of productivity growth after 1973. Edward Denison, however, found that capital played little or no part in the slowdown, and Martin Baily found an important role for capital only by attributing the obsolescence of much of the existing capital stock to major structural changes in the economy. ${ }^{2}$

The evaluation of trends in capital's contribution to output growth is affected significantly by the choice of the economic sector for analysis. Total GNP includes the activities of agriculture, government, households, nonprofit institutions, residential housing, and the rest of the world, all of which seem far removed from the current discussion of business capital formation. This paper analyzes only the nonfarm, nonresidential business economy. The definition of the economic sector is the same as that which the U.S. Bureau of Labor Statistics calls nonfarm business in its reports on productivity, except that this paper excludes tenant as well as owner-occupied housing. The exclusion of the farm sector is important because the shift of employment from farms to the nonfarm economy, which essentially stopped in the mid-1960s, has major effects on the measurement of trends in productivity and on the capital-labor ratio. The exclusion of housing has important implications because it alters the growth of the capital stock and reduces capital's share of total factor payments. Nonresidential fixed investment data are those published in the national income accounts except for the deduction of investment by farms and nonprofit institutions. Nonfarm inventory stock is measured in the same way as reported in the national

2. Martin Neil Baily, "Productivity and the Services of Capital and Labor," BPEA, 1:1981, pp. 1-50; Edward F. Denison, "The Interpretation of Productivity Growth in the United States," paper presented at the Conference of the Royal Economic Society, London, July 22, 1982; John W. Kendrick, "International Comparisons of Recent Productivity Trends," in William Fellner, ed., Essays in Contemporary Economic Problems, 1981-82 edition (American Enterprise Institute, 1981), pp. 125-70; and J. R. Norsworthy, Michael J. Harper, and Kent Kunze, "'The Slowdown in Productivity Growth: Analysis of Some Contributing Factors," BPEA, 2:1979, pp. 387-421. 
income accounts, and the index of land value is assumed to be unchanged in constant prices.

In current dollars the contribution of capital to output is measured by the sum of the income payments to capital-depreciation, interest rent, property taxes, corporate profits before tax, and proprietor income. ${ }^{3}$ But these data cannot be related to physical measures of output and labor inputs because there is no suitable price deflator for capital income. Thus most studies have attempted to obtain a measure of capital inputs by computing a capital stock in constant dollars and then specifying the relation between the stock of capital and the flow of services.

Within the national income accounts the gross stock of equipment and structures is estimated by the perpetual-inventory method as the sum of all past investment minus retirements. Retirements are estimated by disaggregating total investment into thirty-four categories within which average service lives are assumed to be constant over time. Retirements within each category are distributed over the interval from 45 percent to 155 percent of the average service life (the Winfrey-S distribution-a particular bell-shaped distribution of retirements around the average service lives). The net stock differs from the gross stock by the deduction of past depreciation, where depreciation is defined as the original cost of the asset spread in equal installments over its lifetime. The estimation procedure is particularly vulnerable to errors in the estimates of effective service lives because such errors will lead to a departure of the estimated gross and net capital stocks from their true values.

The use of these estimates of capital stock in the construction of an index of capital services has produced disagreements about how to handle quality change between assets of different vintages, deterioration in the efficiency of a unit of capital as it ages, and the aggregation of heterogeneous components of the capital stock. Several recent studies

3. I adjusted the capital income component of proprietor's income to exclude the payment for their own labor. This adjustment was made on the basis of data from the U.S. Bureau of Labor Statistics in which it is assumed that the self-employed earn a wage rate equal to employees in the same industrial sector. This procedure is employed by the Bureau of Labor Statistics in computing the most commonly used measures of labor productivity. Property taxes are included as part of capital income, not out of any conviction that they are paid by capital, but to ensure that capital's share of total factor payments is not understated. Sales taxes and other indirect taxes are excluded from the measure of output valued at factor cost. 
Figure 1. Alternative Estimates of Capital Service Flows as Capital Ages

Percent of initial service flow

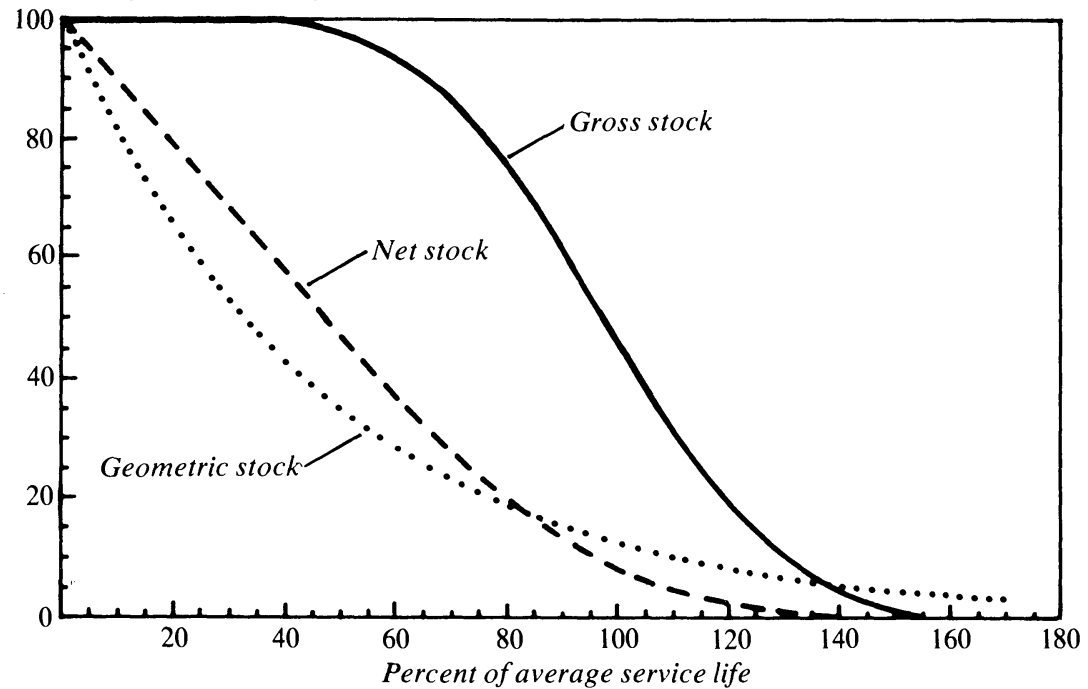

Source: Author's calculations as described in the text.

have clarified the issues of quality change. ${ }^{4}$ The issue does introduce a major source of potential measurement error, but there is no reason to anticipate a strong bias in the current procedures toward overestimating or underestimating the size of the stock.

In the section on empirical measures of capital services below I examine three alternative assumptions about the deterioration of capital. They are illustrated in figure 1. The first assumption, labeled gross stock, is that a unit of capital yields a constant flow of service throughout its lifetime (like a light bulb). The second assumption is that the efficiency of a unit of capital declines in a straight line over its lifetime. The net stock measure corresponds to such a pattern, even though that is not the purpose for which it was constructed. The third alternative assumes that

4. See Jack Triplett, "Concepts of Quality in Input and Output Price Measures: A Resolution of the User Value-Resource Cost Debate," in Murray Foss, ed., The U.S. National Income and Product Accounts: Selected Topics (National Bureau of Economic Research, forthcoming); and Franklin M. Fisher and Karl Schell, The Economic Theory of Price Indexes (Academic Press, 1972). For a survey of the empirical studies, see Jack E. Triplett, "The Measurement of Inflation: A Survey of Research on the Accuracy of Price Indexes," in Paul H. Earl, ed., Analysis of Inflation (Lexington Books, 1975), pp. $19-82$. 
efficiency declines at a geometric rate (double-declining balance). The geometric stock assumption implies capital loses most of its efficiency in the early years of its lifetime. Note that both the gross and net capital stock measures decline at an accelerated rate after 45 percent of the asset's average life has been reached because they incorporate a distribution of retirements about the average service life. That is, each unit of capital deteriorates at a constant rate; but, in addition, some units are being discarded. ${ }^{5}$

The aggregation of components of the capital stock is based on a divisia index that weights the growth in the components of capital services by their share in the total income of capital. I followed the methodology of Edward Denison by allowing for differences in the net rate of return between the corporate and noncorporate sectors in dividing total capital income between three asset groups of depreciable capital, land, and inventories. The final asset weights differ from Denison's only because they are computed for gross rather than net (inclusive of depreciation) capital income in order to relate them to gross output. ${ }^{6}$

Direct aggregation of the components of the capital stock does not reflect the steady shift toward assets with shorter lifetimes that occurred throughout the postwar period. ${ }^{7}$ Yet that shift increased the flow of gross capital services per unit of capital because, with shorter-lived assets,

5. When evaluating the reasonableness of the alternative assumptions it is important to distinguish between the productivity concepts of the capital stock and a wealth concept. A wealth measure of capital declines both because of declines in efficiency of use and because of the elimination of another year of an asset's lifetime. A wealth measure of capital should represent the present value of the future service flow. A useful discussion of these issues is found in Michael J. Harper, "The Measurement of the Productive Capital Stock, Capital Wealth, and Capital Services," Working Paper 128 (Bureau of Labor Statistics, June 1982).

6. I also investigated the use of the asset shares that are obtained from the formula for the rental price of capital as discussed in the Norsworthy, Harper, and Kunze study. Because they include capital gains and losses, the share weights have far greater variability on a year-to-year basis, but the trend of changes in the weights is the same, and they had minor effects on the results.

7. The average service life of new investment was roughly constant up to 1967 but steadily declined thereafter from 21 years to 18.3 years in 1980 . The overall decline is strongly correlated with inflation. That correlation is reflected only in the shift from structures to equipment. Within the equipment category the decline in durability is not correlated with inflation, and there is a slight increase in the durability of investment within the structures category. Such shifts in durability are not a serious problem for studies such as Denison's that focus on net output because the effect of the shift is reflected in depreciation, resulting in lower net relative to gross output. 
the same total value of services was provided over a shorter period of time. The estimates of capital services were adjusted to account for this shift. ${ }^{8}$

\section{EMPIRICAL MEASURES OF CAPITAL SERVICES}

The basic measures of capital services and their effects on output and productivity growth are shown in table 2 . The focus on three subperiods since 1948 follows the general practice of the growth-accounting studies, which argue that a productivity growth slowdown began around 1967 but that the period of substantial shortfall occurred after 1973. Within the private nonfarm, nonresidential sector, labor-productivity growth slowed from an annual average of 2.5 percent in the 1948-67 period to 0.5 percent between 1973 and 1980 .

Stock of Equipment and Structures. The estimation of capital services begins with a measure of the capital stock. To illustrate the sensitivity of the conclusion to assumptions about the deterioration of its efficiency as capital ages, estimates of capital-stock rates are presented for ageefficiency patterns based on the gross and net stock of equipment and structures and on a geometric efficiency decline of double-declining balance. All three of these measures show some slowing of capital stock growth after 1973 in comparison with the high growth of 1967-73; but the amount of the slowdown varies from 0.5 percentage point annually for the gross stock to 1.2 point for the geometric stock.

The three measures differ about a post-1973 slowdown when compared to the longer postwar period of 1948-67 because the growth of the gross stock is greater and the geometric and net stock growth rates are lower for the recent period. The major reason for this difference lies with the estimated growth rate for structures; the equipment stock has grown slightly faster in the recent period on all three efficiency assumptions. The extended period of depressed investment between 1929 and 1946

8. To adjust for the change in durability, the present value of the service flow was equated to the original purchase price with an after-tax rate of interest of 5 percent and a tax rate on net capital income of 25 percent. For the gross and net stock assumptions about the path of efficiency as capital ages, the present value calculation yielded a ratio that was multiplied by the gross and net capital stocks respectively in each of the thirty-four categories of plant and equipment for which the U.S. Bureau of Economic Analysis applies different assumptions about service lifetimes. For the geometric stock I used actual depreciation plus an after-tax return on capital of 5 percent. 
Table 2. Rates of Growth of Output and Inputs for the Private Nonfarm Nonresidential Sector, Selected Periods, 1948-80

Percent

\begin{tabular}{|c|c|c|c|}
\hline Measure & $1948-67$ & $1967-73$ & $1973-80$ \\
\hline Output & 3.8 & 3.9 & 2.1 \\
\hline Labor (man-hours) & 1.2 & 1.8 & 1.6 \\
\hline Labor productivity & 2.5 & 2.1 & 0.5 \\
\hline Stock of equipment and structures & & & \\
\hline \multicolumn{4}{|l|}{ Direct aggregation } \\
\hline Gross & 3.4 & 4.5 & 4.0 \\
\hline Net & 4.1 & 4.7 & 3.7 \\
\hline Geometric & 4.2 & 4.6 & 3.4 \\
\hline \multicolumn{4}{|l|}{ Adjusted for durability } \\
\hline Gross & 3.7 & 4.9 & 4.5 \\
\hline Net & 4.3 & 5.1 & 4.3 \\
\hline Geometric & 4.3 & 4.7 & 4.3 \\
\hline \multicolumn{4}{|l|}{ Contribution to output ${ }^{\mathrm{a}}$} \\
\hline \multicolumn{4}{|l|}{ Equipment and structures } \\
\hline Gross & 0.7 & 1.0 & 0.9 \\
\hline Net & 0.8 & 1.0 & 0.8 \\
\hline Geometric & 0.8 & 1.0 & 0.8 \\
\hline \multicolumn{4}{|l|}{ Capital and land } \\
\hline Gross & 0.9 & 1.1 & 0.9 \\
\hline Net & 1.0 & 1.2 & 0.9 \\
\hline Geometric & 1.0 & 1.1 & 0.9 \\
\hline \multicolumn{4}{|l|}{ Capital and land (1972 income shares) } \\
\hline Gross & 0.8 & 1.1 & 0.9 \\
\hline Net & 1.0 & 1.2 & 1.0 \\
\hline Geometric & 0.9 & 1.0 & 1.0 \\
\hline \multicolumn{4}{|l|}{ Total factor productivity ${ }^{\mathrm{a}}$} \\
\hline Gross & 1.9 & 1.4 & -0.1 \\
\hline Net & 1.8 & 1.4 & -0.1 \\
\hline Geometric & 1.8 & 1.5 & -0.1 \\
\hline
\end{tabular}

Source: Author's calculations as described in the text.

a. Includes the adjustment of plant and equipment stock for changes in durability.

led to a large decline in the stock of structures when measured on a net or geometric basis; but given the long service lives of structures, discards-and thus the gross stock-were affected to a much smaller extent before 1948. As a result, the postwar measure of the gross stock begins at a much higher level than the other two and grows more slowly.

The adjustment for durability increases the growth of capital services in all periods and narrows the range of variability in the estimated magnitude of the post-1973 slowdown. The net stock and geometric 
variants no longer imply slower growth in capital services after 1973 when compared to $1948-67 . .^{9}$

Effects on Output. The contribution of capital inputs to the growth of output is the product of their growth rates multiplied by their share of total factor income. Because capital's share in income, and hence its contribution to production, is relatively small, no appreciable proportion of the slowdown in productivity growth can be attributed to the modest changes in the rate of capital accumulation that have occurred. With a gross income share (depreciation, property taxes, and net capital income divided by total factor income) that averages about 20 percent, the observed decline in the growth of equipment and structures is simply too small to have contributed much to the shortfall in productivity since 1973. Compared with 1948-67, there is no decline in the contribution of equipment and structures to output growth after 1973, and compared to the $1967-73$ period, the decline is only 0.1 to 0.2 percentage point.

A broader measure of capital inputs (tangible assets) can be constructed by adding the value of land and inventories to equipment and structures. ${ }^{10}$ The income share for this total capital measure is larger, about 25 percent, but the index decelerates less after 1973. As a result, the estimated slowdown in the contribution of capital to output varies from zero to 0.3 percent annually, depending upon the specific assumptions about efficiency declines and the periods used for comparison.

Most of what little decline there is in capital's contribution to output growth after 1973 can be attributed to the fall of its share of income rather than to any slowdown in the rate of physical accumulation. If capital's share of income is held constant at its 1972 value, as shown in table 2 , there is no consistent evidence of a slowdown.

The decline in capital's contribution to output growth may simply be a reflection of business cycle fluctuations because the income share of capital declines during recessions. The cyclical factor is a particular problem for the post-1973 period. Cyclical influences are of less importance in the earlier periods because either they involve a long time-span, 1948-67, or the beginning and end years represent periods of comparable

9. I computed alternative measures of capital services based on after-tax discount rates of 3 and 7 percent, but the results do not seem to be sensitive to the choice of a discount rate.

10. The aggregation uses a divisia index in which growth in the component indexes is multiplied by their share of gross capital income. 
resource utilization. The cyclical issues are more directly addressed below in an examination of the pattern of change in the income earned by capital.

Total Factor Productivity. The preceding estimates of the effect of capital growth on output growth have not considered the change in capital intensity relative to labor inputs-the capital-labor ratio. Several studies focus on that ratio, which as table 1 shows, slowed substantially in the 1970s for the total economy.

For the nonfarm business economy, however, the change in the capital-labor ratio is less dramatic, and it can account for only a small part of the productivity slowdown. The exclusion of the farm sector and the adjustment of capital for changes in durability both reduce the slowdown in the capital-labor ratio in table 2 (which can be inferred by subtracting the growth rate of man-hours from the capital growth rates for any of the measures of capital shown here). The limited contribution of capital to the productivity slowdown is made explicit in table 2 by the estimate of the growth of total factor productivity (output per unit of capital and labor). The decline in total factor productivity growth parallels that of labor productivity. The growth in the former falls from an annual average of 1.8 percent in 1948-67 to -0.1 percent in the period after 1973, a slowdown of 1.9 percentage point. The growth in labor productivity slows by 2 percentage points from 2.5 percent in 1948-67 to 0.5 percent after 1973 . Thus a slower rate of capital-labor substitution accounts for 0.1 percentage point of the slowdown in labor productivity.

Doubts about the importance of the slower growth of the capital-labor ratio are reinforced by noting that other industrial countries have experienced a decline in productivity growth similar to that of the United States. Yet there was no acceleration of growth in labor supply in most of those countries, and their capital-labor ratios continued to rise after 1973.

I am as puzzled as everyone else about why productivity growth has slowed so sharply; but it would appear, under normal accounting procedures, that capital formation is not contributing much to the story. ${ }^{11}$

11. I have made no adjustment to the productivity data for the effects of increased government regulation. There seems to be a consensus in the major growth-accounting studies that the diversion of inputs resulting therefrom is $0.1-0.2$ percentage point in the post-1973 productivity slowdown. If one could be sure that regulation operated only through increasing required capital inputs, it could be assigned to capital, and thereby a 
PREMATURE OBSOLESCENCE OF CAPITAL

Above it was assumed that capital experiences, on average, a decline in its economic usefulness as it ages that was expected when it was purchased. It has been suggested, however, that much of the existing capital stock has been made obsolete by major unanticipated structural changes that led to a severe misallocation of capital during the past decade. Because the measured growth of the capital stock does not reflect such influences, the stock and the flow of services from capital may be overstated. ${ }^{12}$

Baily has recently argued that the observed decline in the market value of corporations relative to the replacement cost of tangible assets, Tobin's $q$, supports the view that existing estimates of the capital stock are overstated. ${ }^{13}$ Baily outlines a vintage capital model that provides a mechanism through which sudden obsolescence affects productivity and market value. His analysis highlights several interesting facets of the productivity puzzle. For example, much casual discussion of the productivity slowdown has argued that technological change has slowed. Yet Baily shows that if technology is embodied, such a slowdown should have raised the market value of firms and Tobin's $q$ because the lifetime of existing capital is extended. Unanticipated obsolescence, however, is consistent with the observed decline in both productivity and market value.

Baily discusses several developments that might increase obsolescence. Their effects on productivity and market value differ and must be distinguished. If capital is misallocated and cannot be used, productivity and market value both drop immediately. If, on the other hand, there is an anticipation of an earlier retirement date because of more efficient future capital, the market value (the present value of future returns) will fall immediately, but the existing capital continues to yield services until it is retired. The latter situation seems applicable to

larger estimate of capital's contribution to the productivity slowdown could be obtained. But there is little justification for ignoring the effects of regulations on other inputs, and it seems preferable to identify them as a separate influence to avoid distorting the causation.

12. The important distinction is between anticipated and unanticipated obsolescence: the former shortens service lives, but there is an offsetting rise in the flow of services per unit as discussed earlier with respect to durability; the latter leads to premature scrappage with no compensating rise in the service flow.

13. Baily, "Productivity and the Services of Capital and Labor." 
something like an oil shock, and the change in the ratio may exaggerate the change in capital services.

The major difficulty with Baily's argument is that he has no direct empirical evidence beyond the fact that the decline in productivity and $q$ occurred at the same time. In commenting on his paper, Robert $\mathrm{J}$. Gordon provides some evidence that the hypothesis was not fully consistent with developments in the electric utility industry in which the energy price changes should have had a large effect. In the airline industry, however, there was a large restructuring of values for planes with different fuel efficiencies. The B-707, which could not be modified with more efficient engines, fell in value and was removed from service, but the DC-8 was modified and continued in use. On the other hand, there was no significant slowing of the growth of labor productivity within that industry. Denison's long-term productivity studies also fail to reveal large fluctuations in total-factor productivity growth during other periods of substantial structural change, such as 1941-47. And the long period of rise in $q$ from 1955 to 1965 is not reflected in an unexpected residual in the conventional growth-accounting studies that assume that obsolescence is gradual and anticipated.

With respect to premature retirements, the U.S. Bureau of Economic Analysis has been attempting to match its estimates of the stock of equipment and structures with direct sources such as census data on the book value of assets. Thus far the wide variation in bookkeeping procedures prevent a close comparison of the annual changes in the two estimates, but an unexpected burst of scrappage should reduce the ratio of capital reported on balance sheets to the corresponding value obtained by the perpetual-inventory method. For manufacturing, the historical cost valuation of gross stocks from surveys of the U.S. Bureau of the Census averages 105.4 percent of the perpetual-inventory valuation in 1967-69. The ratio declines to an average of 103.4 in 1974-76..$^{14}$ This change is in the direction suggested by the obsolescence hypothesis, but the magnitude is small. Manufacturing firms did not literally scrap capital in the magnitudes required to account for a significant portion of the productivity slowdown.

Baily's hypothesis is not simply one of increased scrappage of capital, however. Some obsolescence might be reflected in planned reductions

14. These data were obtained from various Annual Surveys of Manufactures; more recent data are not yet available. 
in utilization. This suggests that some of the existing survey data that obtain responses from firms about capacity utilization might provide useful evidence about the growth in capital through its correspondence with the concept of capacity. ${ }^{15}$ The Federal Reserve Board's index of manufacturing capacity is constructed by dividing survey reports on capacity utilization into indexes of industrial production for a detailed set of manufacturing industries, smoothing the result to remove cyclical influences, and aggregating with value-added weights. ${ }^{16}$ I regressed this capacity measure on the gross stock of equipment and structures within manufacturing and a time trend (representing technical change) for 195567 and extrapolated thereafter to determine if that relation had changed in recent years. The results are shown in figure 2 . The amount of capacity anticipated from the capital stock data begins to exceed the actual amount of capacity inferred from the survey in the early 1970s and grows to 24 percent above the actual value by $1980 .{ }^{17}$ The results suggest an overstatement of the effective capital stock. They are supported by the capacity utilization survey published by the Bureau of Economic Analysis that shows a similar pattern, although the magnitude of the 1980 discrepancy is reduced to about 20 percent.

Part of the discrepancy may be accounted for by the growth in investments to reduce environmental pollution and increase worker safety. If such investments are assumed to have no net effects on capacity, their subtraction from the capital stock would reduce the overestimate of capacity in 1980 by about 7 percent. ${ }^{18}$ This still leaves a residual of 10 to 15 percent.

15. In an earlier article I found only a weak correlation between capital and capacity in individual industries, so I have some skepticism about the meaning of the aggregate relation. But many would argue that, because I was mistaken then about the imminence of capacity shortages, I was also wrong to discount the relation between capital and capacity. See Barry Bosworth, "Capacity Creation in the Basic-Materials Industries," BPEA, 2:1976, pp. 297-341.

16. The methodology is explained in Board of Governors of the Federal Reserve System, Federal Reserve Measures of Capacity and Capacity Utilization (February 1978), pp. 12-19. The resulting aggregate index is virtually identical to the results of the McGrawHill survey of capacity on a regular basis.

17. If the period of estimation is extended into the 1970s, the coefficient on the capital stock is steadily reduced and the role of the time trend becomes greater.

18. Another study finds that pollution abatement capital can account for all of the shortfall until 1978 because the statistical results show an elasticity of capacity with respect to other capital greater than unity and the environmental capital has a negative coefficient 
Figure 2. Actual and Predicted Capacity in Manufacturing, 1955-80

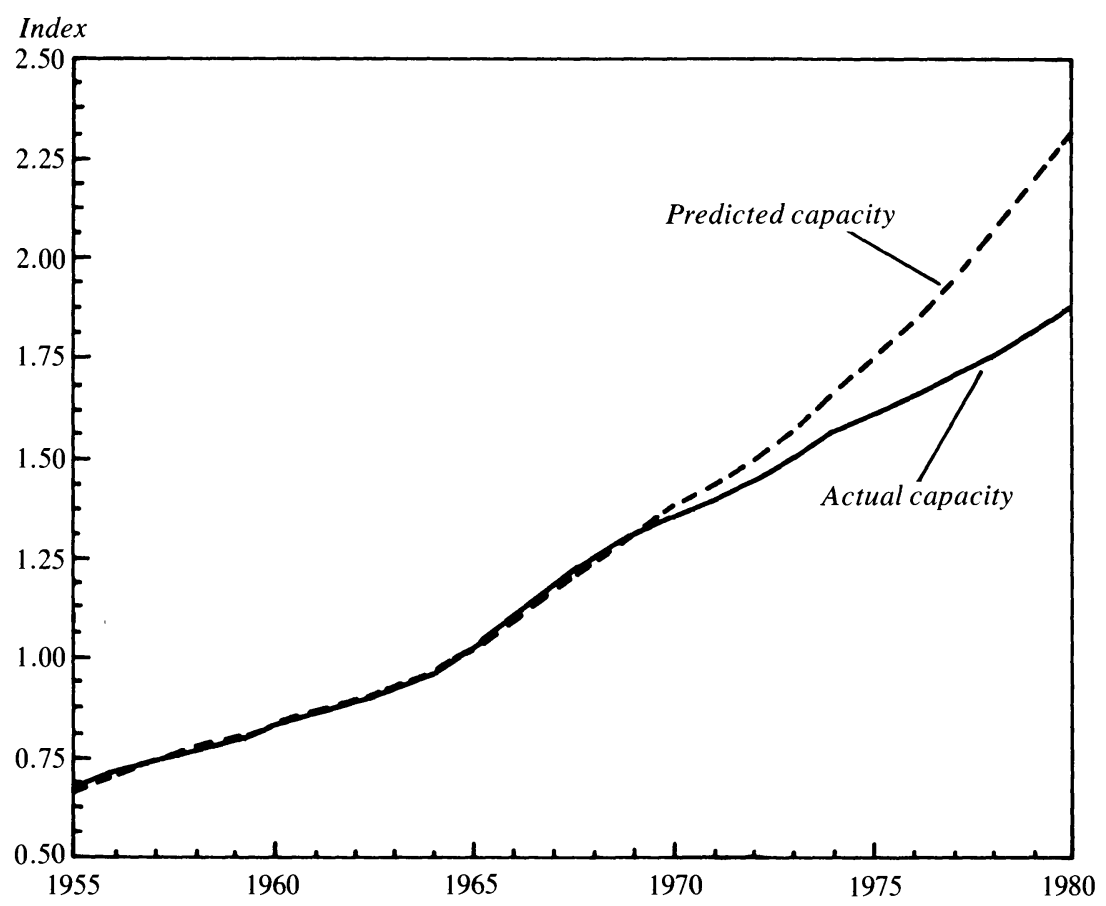

Source: Author's calculations as described in the text, using $\ln C A P=-13.34+0.0186$ time $+1.002 \ln K G$, where $K G$ is gross capital stock in manufacturing and time is time trend.

A final check on the hypothesis of reduced utilization is obtained by examining data on the prevalence of second and third work shifts. A change toward less frequent reliance on multiple work shifts would be consistent with reduced utilization of capital. Since 1960 the Bureau of Labor Statistics has obtained data on the proportion of workers in manufacturing employed on late shifts as part of its area wage surveys. Those surveys show a steady rise in the prevalence of second and third shifts from a national average of about 22 percent of the work force in the early 1960 s to 28 percent in 1972-75, with no pronounced cyclical pattern. In 1976-77 the percentage declined slightly to 27 percent. A survey of households to determine the characteristics of the labor force

in a regression estimated over the 1954-78 period. See Ronald Rost, "Capacity Neutral Investments and Capacity Measurement in Manufacturing," Journal of Industrial Economics, forthcoming. 
from 1973 to 1978 indicated no change in the proportion of workers on late shifts. ${ }^{19}$ If it is assumed that continuation of the previous trend would have led to 30 percent of the work force on late shifts in 1977, the decline in the intensity with which capital was used reduced the effective capitaloutput ratio by about 2 percent $(0.03 / 1.27)$. That would imply a one-time decline of 0.5 percent in capital's contribution to output. Alternatively, if the trend growth in the percentage of late shifts is evaluated at 0.5 percent annually and it stopped after 1973, the effect on growth in labor productivity would be about 0.1 percent annually.

The results of these various tests of the obsolescence hypothesis are ambiguous. I conclude that, although the effects are in the right direction for both premature retirements and reduced utilization, the magnitudeexcept in the case of manufacturing capacity-does not seem to be sufficient to account for a major restatement of the growth in capital services during the 1970s. At present I am inclined to view the obsolescence hypothesis as being more applicable as a potential explanation for the decline in market value (because of the anticipation of future energyefficient investments) than as an explanation for a large drop in the flow of current capital services.

\section{Capital Income}

The adequacy of capital formation can also be evaluated by reference to its rate of return. If capital is becoming the relatively scarce factor in production, its rate of return should rise. Indirectly this issue was an element of the above analysis because capital's share of income was a critical element in the calculation of the contribution of capital to output. Before 1967, capital's share of gross factor income within the nonfarm, nonresidential sector fluctuated within a narrow band of 25 to 28 percent of total income with no evidence of any secular trend. After 1967, however, it fell sharply to only 22.5 percent by $1980-80$ percent of the 1967 share. During this time the depreciation component rose substantially and the property tax share declined. Thus by 1980 the share of total-factor income represented by net capital income (profits before tax

19. Janice N. Hedges and Edward S. Sekscenski, "Workers on Late Shifts in a Changing Economy,"' Monthly Labor Review, vol. 102 (September 1979), pp. 14-22. 
and interest payments) had fallen to 55 percent of its 1967 value. A collapse in capital income of this magnitude requires more explanation. ${ }^{20}$

THE RATE OF RETURN ON CAPITAL

Movements in capital's share of total output, $Y C A P / Y$, can be decomposed into two components: the before-tax rate of return on total tangible assets, $Y C A P / K$, and the ratio of tangible assets to total output, $K / Y$. Thus

$$
Y C A P / Y=(Y C A P / K) \cdot(K / Y) .
$$

This decomposition reveals two interesting facts. First, the ratio of tangible assets to output was essentially free of any trend throughout the 1950 s and 1960 s, but then rose during the 1970 s to a 1980 level 23 percent above the 1967 value. ${ }^{21}$ This shift was evident in the constant dollar relation of table 2, in which all the measures of capital grew more rapidly than real output after 1967. But the shift is amplified in the ratio of tangible assets to output in current dollars because capital goods prices rose more rapidly than those for output in general. Second, this rise in the value of assets relative to output combined with the previously noted decline in capital's share of total output, $Y C A P / Y$, produces a sharp

20. Some economists prefer not to view property taxes as a component of capital income and to classify them as an indirect tax as in the national income accounts. In the remainder of this paper capital income excludes property taxes so as not to overstate the amount of decline.

21. Neither the gross nor net capital stocks used in the analysis of productivity growth provide appropriate conceptual measures of wealth and income for purposes of computing a rate of return because they do not measure the present value of the future flow of capital services. The capital stock appropriate to measuring capital's contribution to output is equal to the corresponding wealth measure only for the case of geometric efficiency decline. The issue is discussed at greater length in Harper, "The Measurement of the Productive Capital Stock." Thus I computed two measures of total assets. The first, referred to as a modified gross stock measure, uses the gross stock of equipment and structures multiplied by the average ratio during $1948-80$ of the net to gross stock. This should yield a wealth measure that is largely free of the influence of changes in the age of capital while being adjusted to a level that yields a measure of the rate of return. The second is based on the double-declining balance measure of the stock of equipment and structures. Because both measures of wealth and the corresponding net income gave virtually identical results for the trend in the return to capital, only the modified gross stock measure is discussed in the text. The value of land is taken from the national wealth accounts of the Flow-of-Funds Division of the Board of Governors of the Federal Reserve System. 
decline in the rate of return on tangible assets, $Y C A P / K$. The net return fell from 11.6 percent in 1967 to 5.6 percent in $1980 .{ }^{22}$

The rate of return on capital and the ratio of tangible assets to output have a substantial cyclical component that tends to overstate the magnitude of change in recent years. To adjust for this, each series was regressed on the utilization of actual GNP relative to potential and the change in real GNP. A cyclically adjusted series was then calculated corresponding to full utilization and a rate of GNP growth equal to that of potential GNP. ${ }^{23}$ Figure 3 shows both the adjusted and unadjusted series for the rate of return and the ratio of tangible assets to output. Compared to a decline of 52 percent in the unadjusted rate of return, the adjusted measure of the rate of return declined during the 1970s to a 1980 value 27 percent below the return earned in 1967-a fall of 3 percentage points (11.2 to 8.2 percent). Cyclically adjusted, the ratio of tangible assets to output declined gradually throughout most of the period and then rose 11 percent between 1967 and $1980 .{ }^{24}$

Other studies have commented on the fall in the return to capital for nonfinancial corporations. ${ }^{25}$ For nonfinancial corporations alone, the fall in the cyclically adjusted net rate of return on capital between 1967 and 1980 was 2.5 percentage points (compared to 3.0 percentage points for the total), and the cyclically adjusted ratio of tangible assets to output rose by 5 percent (rather than the 11 percent for the total).

In computing capital income for the broader sector examined here, which includes noncorporate, nonfarm business, I removed the labor component of noncorporate income on the assumption that the self-

22. The conclusion is the same if the gross return (including depreciation and property taxes) is used because a rise in the depreciation component is offset by a decline in the property tax rate.

23. I experimented with a variety of formulations of the cyclical adjustment. The important point seems to be that a level effect should be included, but it makes little difference if that term is the utilization of potential output, capacity utilization in manufacturing or the unemployment rate. The method used in this paper yielded the largest cyclical adjustment.

24. In contrast to the point made above, that obsolescence caused an early retirement of capital, it might be argued that retirements were postponed to accommodate the accelerated growth of the labor force and that the increased importance of older, inefficient capital is responsible for the fall in the rate of return. The official estimates of the capital stock would not reflect such an extension of service lives, however, and the reported rate of returns on capital should have risen.

25. See, for example, William D. Nordhaus, "The Falling Share of Profits," BPEA, $1: 1974$, pp. 169-208. 
Figure 3. Rate of Return on Tangible Assets and the Ratio of Tangible Assets to Output: Actual and Cyclically Adjusted Values, 1950-80
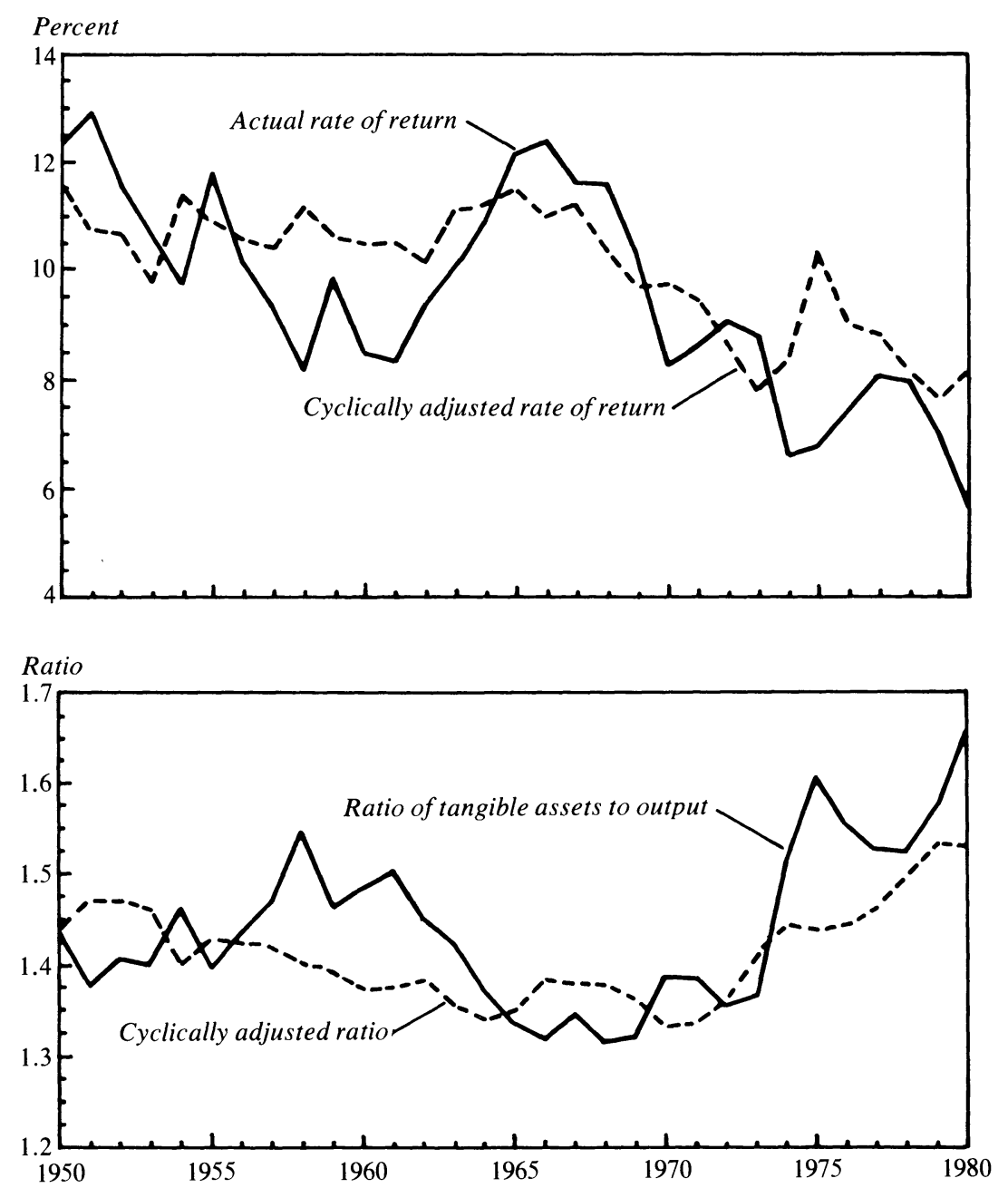

Source: Author's calculations as described in the text.

a. Tangible assets include equipment, structures, land, and inventories.

employed earn a wage rate equal to that of employees. This results in a measure of net noncorporate capital income that falls rapidly during the 1970s. Throughout the postwar period the before-tax return on noncorporate capital has been below that of corporations, but the differential widened sharply during the 1970 s. 
The generally low before-tax return to capital in this sector may result from the more favorable tax treatment and nonpecuniary benefits of being self-employed; and the deterioration during the 1970s is consistent with the observed sharp increase in the number of business bankruptcies. However, the behavior of noncorporate income does raise questions about the accuracy with which it is measured. ${ }^{26}$

The apparent decline in capital income within the noncorporate sector is bound to give rise to an explanation based on a presumed growth in the underground economy. I do not feel that there is any significant evidence at present to support that hypothesis. A recent paper by Denison, based on an examination of employment data, argues convincingly that the importance of such a phenomenon on the overall GNP estimates cannot be very substantial. ${ }^{27}$

The measured rate of return on capital could be distorted in the opposite direction by the sharp rise in energy prices and the profits of the domestic energy industry during the 1970s. The available data on the value of tangible assets, however, do not include the rise in the value of mineral reserves such as petroleum, natural gas, and coal. Thus a sharp rise in the reported rate of return within the energy industry could augment the average rate of return so that the extent of the decline in other industries is not readily seen.

Because a consistent time series on the value of natural resource reserves is not available, I recomputed the net rate of return after

26. Criticism might be directed at the assumed wage rate. In fact, other studies have assumed that noncorporate capital earns a return equal to that in the corporate sector, allocating the shortfall to labor income. Denison prorates the discrepancy over both components of factor income.

Using the nonfinancial corporate sector to measure the return on capital also introduces problems, however. There are no reliable data on which to base the split of total tangible assets between the corporate and noncorporate sectors. Given the methods of estimation, it would seem that the value of tangible assets is more accurately measured for total business than for either the corporate or noncorporate component alone.

27. Edward F. Denison, "Is U.S. Growth Understated Because of the Underground Economy?" Review of Income and Wealth, Series 28 (March 1982), pp. 1-16. The major source of information on nonfarm proprietor income is tax returns. One might argue that the self-employed have evaded taxes to a much larger extent in the 1970s than in previous decades. In actual practice, however, the Bureau of Economic Analysis adjusts the tax data by assuming that the amount of additional income that would be disclosed on each return is the same as that found in a special sample of audited returns. This adjustment added $\$ 13.7$ billion in 1976 or 24.2 percent of income reported on tax returns. Thus for tax evasion to change the trend of proprietors' income it would be necessary to assume that the audits are becoming increasingly ineffective. 
excluding net profit income of the oil and natural gas industries. According to this method of calculation, the rate of return, excluding energy, declined by a larger amount after 1967 , but not by a dramatic amount. Cyclically adjusted, the net rate of return is reduced by 15 percent in 1980 and the post -1967 decline is expanded by 0.6 percentage point. The effect is slightly smaller for the nonfinancial corporate sector, in which the post- 1967 decline is enlarged by 0.4 percentage point.

Upon reflection, however, one notes that the deduction of energy industry profits does not seem correct for most purposes for which a rate of return is desired. The division of total capital income by tangible assets yields an average rate of return rather than the marginal return appropriate for evaluating current investment. One effect of the oil price rise was to transfer income from old capital to the energy industry-thus depressing the realized return on the capital. On that basis, it would be desirable to include the transfer in the overall measure of the income to capital in order to maintain as much correspondence as possible between movements in the average and marginal return. The rise in the profit of the domestic energy industry, however, is not a good measure of that transfer because some of it was paid to foreign suppliers. On the other hand, a major portion of the total rise in the economic rent paid to energy producers represented a transfer from owners of existing consumer durable goods and private residences. What is needed is a measure of the differential energy cost of new versus existing business capital, and that is not yet available.

\section{TAXATION OF CAPITAL INCOME}

The rise in the capital-output ratio and the large decline in the beforetax rate of return on capital could be explained by a decline in the tax on capital income. A reduced tax wedge would lead to an acceleration of capital formation, with a rise in the desired capital-output ratio and a compensating fall in the before-tax rate of return. It is far more common, however, to argue that there has been a sharp increase in the taxation of capital income during the $1970 \mathrm{~s}^{28}$

28. The pattern of a fall in the rate of return and a rise in the ratio of tangible assets to output is also not what one would expect if increased public sector borrowing in capital markets had raised the required return and reduced business investment-another argument that has often been made in recent years. 
The most extreme estimate of this increased tax burden is provided by the various studies with which Martin Feldstein has been associated. An example of the total effective tax on capital income of nonfinancial corporations is provided in a recent study by Feldstein, Poterba, and Dicks-Mireaux (hereafter FPD study) and is summarized in table 3.29 The total tax (corporate plus personal) is estimated to be just a little less than 70 percent during the late 1970 s and has increased by 10 percentage points in the last decade-in fact, on an annual basis the increase is 16 percentage points from the minimum of 53.5 percent in 1965 to 69.4 percent in 1979 (with a maximum tax rate of 84.7 percent in the recession year of 1974). The major surprise is the personal tax component, which shows a rise in the tax rate from a low of 11.6 percent in 1960-64 to an average of 20.5 percent in $1975-79 .{ }^{30}$ This implies a rise in the personal tax rate on capital income (after deduction of corporate taxes) received by individuals and financial institutions from 23 percent in 1960$64(11.6 /(1-0.494))$ to 39 percent in $1975-79$. The personal tax rates used in the FPD study are averages of marginal tax rates weighted by the distribution of interest and dividends among tax brackets. These individual rates do rise over the 1970s, but the conclusion of a sharp rise in the effective tax rate is dominated by the shifting distribution of corporate income away from dividends and retained earnings toward interest and by the growing importance of capital gains in an economy of high inflation. ${ }^{31}$

29. Much of this paper is an update of an earlier one. See Martin Feldstein and Lawrence Summers, "Inflation and the Taxation of Capital Income in The Corporate Sector," National Tax Journal, vol. 32 (December 1979), pp. 445-70.

30. The definition of capital income net of depreciation is the same as that used earlier in this study except for the deduction from capital income of the estimated annual cost of holding noninterest bearing financial assets (cash, demand deposits, and net trade credit) and the inclusion of property tax payments as part of net income. The first item reduces income by about 7 percent in 1979 compared to 3 and 2 percent in 1969 and 1959 , respectively. Obviously the property tax assumption also raises the effective tax rate since equal amounts are added to the numerator and denominator. Overall, these two definitional changes raise the effective corporate tax rate by 9.4 percentage points in $1979,8.4$ points in 1969 , and 6.3 points in 1959.

31. The FPD study takes appropriate account of the distribution of asset holdings among households and financial institutions with differing tax rates. Under the usual assumptions that the corporate tax rate exceeds the tax rate of interest recipients, a rise in the nominal interest rate reduces the net taxation of capital income because the savings in corporate taxation occasioned by its deductibility as an expense exceeds the tax paid by the recipients. In the FPD study this differential is small because of the very high marginal tax rate assigned to personal interest income. 
Table 3. FPD Study Estimate of Effective Rates of Taxation on the Capital Income of Nonfinancial Corporations, Selected Periods, 1955-79

Percent

\begin{tabular}{lccccc}
\hline & \multicolumn{5}{c}{ Tax rate } \\
\cline { 2 - 6 } \multicolumn{1}{c}{ Tax } & $1955-59$ & $1960-64$ & $1965-69$ & $1970-74$ & $1975-79$ \\
\hline Corporate taxes $^{\mathrm{a}}$ & 56.6 & 49.4 & 45.4 & 50.2 & 47.2 \\
Personal taxes & 12.3 & 11.6 & 12.8 & 19.5 & 20.5 \\
$\quad$ Dividends & 8.6 & 7.7 & 6.8 & 6.6 & 6.5 \\
Capital gains & 2.2 & 1.8 & 3.2 & 6.2 & 7.0 \\
Interest & 1.5 & 2.1 & 2.9 & 6.7 & 6.9 \\
Total taxes & 68.9 & 61.1 & 58.2 & 69.7 & 67.7 \\
\hline
\end{tabular}

Source: Martin Feldstein, James Poterba, and Louis Dicks-Mireaux, "The Effective Tax Rate and the Pretax Rate of Return," Working Paper 740 (National Bureau of Economic Research, 1981), table 3.

a. Includes federal and state and local corporate income taxes and property taxes.

These estimates of the personal tax on capital income contrast with those of a study by Eugene Steuerle that attempted to measure the effective rate of taxation from a completely different perspective. ${ }^{32} \mathrm{He}$ measures the total net income from all capital after deduction of business taxes and compares that with the amount of income subject to tax under the personal income tax system. ${ }^{33}$ The definition of income is net of inflation returns and would thus correspond to an economic concept of capital income. He estimates that only 32 percent of the $\$ 305.5$ billion of capital income in 1979 was subject to tax on individual returns. Using data on the distribution of taxes and capital income by tax bracket, Steuerle estimates an average marginal tax rate of 30.6 percent on reported taxable income from capital. ${ }^{34}$ Thus he obtains a tax rate on the total capital income of individuals of 10 percent in $1979(0.32 \times 30.6)$ compared to 39 percent implied in the FPD study for nonfinancial corporate income.

The major source of difference between these two conclusions about capital income taxation is coverage: Steuerle focuses on a broad definition of the total income from capital, while the FPD study is concerned

32. Eugene Steuerle, "Is Income from Capital Subject to Individual Income Taxation?"' Public Finance Quarterly, vol. 10 (July 1982), pp. 283-303.

33. He defines capital income broadly to include owner-occupied housing and income from consumer durables but deducts the associated business expenses. One-third of proprietor's income is assigned to capital; the rest is allocated to labor.

34. The methodology for obtaining the average marginal tax is similar to that in the FPD study, but the tax is net of deductions for interest expenses and other taxes. 
only with capital invested in nonfinancial corporations. But the distinction has important policy implications. Steuerle may be right that, on average, capital income is not heavily taxed in the individual tax system, but there are enormous variations in the effective tax on different types of capital. Steuerle characterizes the personal income tax as a progressive wage tax, accompanied by a penalty tax on the realization of some types of capital income. The FPD study focuses on one component of capital income that does have such a penalty tax.

The FPD study incorporates several assumptions that may lead to an overstatement of the level of the effective tax rate and the extent of its increase. First, the study makes no allowance for the evasion of taxes that results from the failure to report about 20 percent of capital income. ${ }^{35}$ Second, the corporate tax rate would have fallen sharply during the 1970s if firms had not chosen to pay unnecessary taxes on inventory capital gains, a voluntary choice which contributed 7 percentage points to the effective tax rate in 1979. Third, the FPD study measures capital gains as the rise in the replacement cost of the capital (price changes in capital goods), rather than actual changes in the market value of firms. While the study does reduce the tax rate on this measure of capital gains to between 5 and 7.5 percent to take account of the deferral of such taxes until the gain is realized, the very large magnitude of the measure of capital gains income (about $\$ 285$ billion in 1979) lead to an estimate of the personal tax burden on nonfinancial corporate income that is larger than the tax actually paid on all capital income as estimated by Steuerle. ${ }^{36}$ Obviously the results would be far different if their estimates had used the actual market value of corporations.

More fundamental, it would seem incorrect to estimate the tax on one component of capital income without taking account of the full investment decision of the taxpayer and his investment options. For example, taxpayers with high marginal rates report interest income because it is

35. Because of withholding, the corresponding figure for wages is estimated at 2 to 3 percent. See Steuerle, "Is Income from Capital Subject to Individual Income Taxation?" p. 2.

36. The discrepancy between market value and the replacement cost measure used by the FPD study represented nearly a trillion dollars in 1979. For some purposes the replacement cost concept may be a more appropriate measure of capital gains, but a simple comparison with the amount of capital gains reported on tax returns would suggest an effective tax rate that is only a fraction of the 5 to 7.5 percent that the FPD study reports. 
an unavoidable counterpart of the holding period requirement to achieve a capital gain or because that income may be offset by a capital loss. ${ }^{37}$ Otherwise, one would have to ask why these taxpayers do not shift to tax-exempt securities. A comparison of the return on taxable and nontaxable bonds suggests a maximum tax rate on interest income of 30 to 35 percent, and a sharp fall in the implied marginal tax rate during the 1970s. If the distribution of interest income by tax bracket is truncated at that point, the average marginal tax rate is much lower than estimated in the FPD study.

Although the FPD study may exaggerate the rise in the effective tax rate in business capital and hence the decline in its after-tax return, there is little reason to believe that effective tax rates have fallen so as to offset the decline in the before-tax return. The inconsistency noted earlier between the alleged shortage of capital on the one hand and a declining rate of return on the other hand remains.

\section{Interest Rates and Inflation}

A large decline in the before- and after-tax returns on tangible assets should be reflected in a parallel movement in the return on financial assets. In fact such a decline would be consistent with the previous results by suggesting that firms respond to a fall in the real cost of funds by expanding their more marginal investments-raising the capitaloutput ratio and reducing the average return. The problem is that the perceived real rate of interest is not observable since it depends on expectations of inflation as reflected in nominal interest rates. A very rough measure based on actual inflation rates is illustrated in table 4 .

There has been an enormous growth in the literature-both theoretic and empirical-explaining the relation between market interest rates and inflation. Those studies usually begin with the Fisher hypothesis that the real rate of interest is independent of the level of anticipated

37. This same point is made more fully in a different context of distributional impacts. See Harvey Galper and Eric Toder, "Transfer Elements in the Taxation of Income from Capital," paper presented at the National Bureau of Economic Research Conference on Research in Income and Wealth, Madison, 1982. 
Table 4. Market Interest Rates, Inflation, and Estimated Real Rates, Selected Periods, 1951-80

Percent

\begin{tabular}{lccc}
\hline Period & $\begin{array}{c}\text { One-year } \\
\text { government } \\
\text { security yield }\end{array}$ & $\begin{array}{c}\text { Inflation } \\
\text { rate }\end{array}$ & $\begin{array}{c}\text { Real interest } \\
\text { rate }\end{array}$ \\
\hline $1951-55$ & 1.82 & 2.91 & -1.09 \\
$1956-60$ & 3.35 & 2.92 & 0.43 \\
$1961-65$ & 3.49 & 0.61 & 2.88 \\
$1966-70$ & 5.96 & 4.09 & 1.87 \\
$1971-75$ & 6.42 & 7.78 & -1.36 \\
$1976-80$ & 8.60 & 7.17 & 1.43 \\
\hline
\end{tabular}

Source: Board of Governors of the Federal Reserve System and the national income and product accounts.

a. The market interest rate is the yield on federal government securities of one-year maturity; the inflation rate is measured by the percentage change in the price deflator for nonresidential fixed investment. All data are measured as five-year arithmetic averages.

inflation. Let $i$ be the nominal interest rate, $r$ the real interest rate, and $\pi$ the expected rate of inflation. Then the Fisher hypothesis is

$$
i=r+\pi \text {. }
$$

The relation was modified by Darby and Feldstein to reflect the influence of the tax rate $(\rho)$ on the real after-tax rate of interest $r^{*}$ :

$$
r^{*}=(1-\rho) i-\pi .
$$

If the after-tax real rate of interest is to remain unchanged by inflation, nominal interest rates must rise by more than the expected inflation rate. ${ }^{38}$

Empirical investigators have experimented with a wide variety of different measures of expected inflation, mechanisms for generating expectations, and alternative interest rate measures. The results have consistently rejected, for both the short run and long run, the classical notion that inflation has no effect on real rates of interest. ${ }^{39}$

There have been several attempts to explain the failure of the Fisher effect to operate. One argument is based on a real balance effect in the

38. Michael R. Darby, "The Financial and Tax Effects of Monetary Policy on Interest Rates," Economic Inquiry, vol. 13 (June 1975), pp. 266-76; and Martin Feldstein, "Inflation, Income Taxes, and the Rate of Interest: A Theoretical Analysis," American Economic Review, vol. 66 (December 1976), pp. 809-20.

39. See, for example, Lawrence H. Summers, "The Nonadjustment of Nominal Interest Rates: A Study of the Fisher Effect," in James Tobin, ed., Macroeconomics, Prices, and Quantities: Essays in Mernory of Arthur M. Okun (Brookings Institution, 1983), pp. 201-44. 
presence of a nonzero elasticity of money demand. Inflation reduces the real value of accumulated assets and raises saving as individuals attempt to rebuild their asset position, reducing the real interest rate. But there is general agreement that this effect is too weak to explain the empirical results and is not consistent with the pattern of the saving rate during episodes of inflation. ${ }^{40}$

Others have attempted to identify periods of low real rates with other changes such as supply shocks that cause a downward shift in the investment function, reduce the demand for credit, and thus lower the equilibrium interest rate ${ }^{41} \mathrm{It}$ is difficult to reconcile such arguments with the earlier finding that investment seems to have been unusually strong over the period as a whole; and in any case the augmented equations that allow for such effects do not obtain a sufficiently large coefficient on the inflation variable.

Two other arguments focus on the behavior of individuals and their investment options: (1) they do not correctly perceive and adjust their expectation of future inflation (confusing the nominal and real rates of return and being guilty of money illusion), or (2) they are unable to act on those expectations because of institutional rigidities and transactions costs that limit their investment options. ${ }^{42}$ Neither argument is very

40. Ibid.

41. Such an argument has been given empirical content in a recent study by James A. Wilcox. See his "Interest Rates, Expected Inflation and Supply Shocks or Why Interest Rates Have Been So Low in the 1970s," paper presented at the National Bureau of Economic Research Conference on Inflation and Financial Markets, Cambridge, Mass., May 1981. Supply shocks, as measured by the ratio of import prices to the GNP price deflator, are shown to have a negative interest rate effect. The supply shock variable seems, however, to be primarily a measure of the 1974 oil price increase, which precipitated a recession that is not explained by changes in other measures such as the nominal money supply and government expenditures.

42. The money illusion argument was stressed in Franco Modigliani and Richard A. Cohn, "Inflation, Rational Valuation, and the Market," Financial Analysts Journal, vol. 35 (March-April 1979), pp. 24-44. A different money illusion argument based on less than full adjustment of wage rates is presented by Levi and Makin. They argue that inflation reduces real wages, raising employment and output, and thereby increasing saving. The result is a lower equilibrium interest rate. Such a result is feasible only because they exclude output from the investment function and capital from the production function. See Maurice D. Levi and John H. Makin, "Anticipated Inflation and Interest Rates: Further Interpretation of Findings on the Fisher Equation," American Economic Review, vol. 68 (December 1978), pp. 801-12. Transaction costs have been cited by many investigators but a recent discussion is found in Arthur M. Okun, Prices and Quantities: A Macroeconomic Analysis (Brookings Institution, 1981), pp. 182-222. 
convincing for the purpose of explaining a low real cost-of-funds for investment.

Although studies of survey data on inflation expectations do find an inconsistency with rational expectations, the sensitivity of inflation expectations at the margin to changes in the actual rate is quite great and does not suggest sustained underprediction of persistent inflation..$^{43}$ The argument also seems inconsistent with the claim that households did see through the veil of inflation in perceiving a low real interest cost of home purchase. More fundamental, a low real rate of interest occasioned by money illusion on the part of savers would not translate into higher business investment unless businessmen had a more accurate view of inflation. That is, the money illusion would have to be asymmetric with respect to suppliers and users of funds. While businessmen may be misled by the high reported return on existing capital valued at historical cost, money illusion would not lead to a fundamental error in evaluating the present value of the future income from a new investment.

With respect to institutional rigidities, it is certainly true that many smaller savers were denied a range of investment options that would allow them to act on their expectations. One would think, however, that at the margin there was a sufficient number of investors who could arbitrage among the various markets. Perhaps a combination of money illusion and various transaction costs is enough to explain the behavior of interest rates, but that combination is a little like the frequent reference to expectations-the last refuge for phenomena that economists do not understand.

Another approach to the problem is to ask about the source of the funds to support the investment of the 1970s. Much of the recent policy discussion has referred to declining rates of saving in the United States. But again the data do not support that statement. Most analysis has focused on the household saving rate. But that is not the most meaningful concept for this purpose. One reason is that business saving by corporations is excluded from household saving, but all net income of unincorporated business is included in household income. This conceptual treatment causes substantial distortions in international data where there are differences in the importance of the corporate form of organization,

43. See, for example, Stephen Figlewski and Paul Wachtel, "The Formation of Inflationary Expectations,"' Review of Economics and Statistics, vol. 63 (February 1981), pp. 1-10. 
but it is also significant over time in the United States where there are substantial variations in the relative rate of growth of corporate and noncorporate income. Another reason is that the income payments among sectors include large amounts of interest payments. Those payments have grown sharply because of the rise in nominal interest rates. Yet much of what is called interest income reflects a repayment of the principal required to maintain the real value of assets and cannot be treated as part of consumers' disposable income. ${ }^{44}$

It is more useful to focus on the total private saving rate because the distinction between business and household saving is not of much interest and many of the intersector interest payments cancel out. ${ }^{45}$ Both concepts of saving are presented in figure 4 as shares of GNP. There is no evidence of a secular decline in total private saving, and in fact the data reveal a small upward trend in the share. ${ }^{46}$ It should be noted that this is an ex post result, however, that could be dictated by the required equality of investment and saving; it need not indicate that there has been no change in planned saving rates.

The uses of saving are shown in the bottom panel of figure 4 . As noted above, business investment has not shown much trend as slower inventory investment offset a slight rise in business fixed investment. Most surprising, in view of all the emphasis on its tax benefits to homeowners during inflationary periods, residential construction took up a smaller share of the nation's resources in the 1970s than in previous decades.

The government deficit, taken as a use of private saving, is small. That is because all levels of government are combined and the federal deficit is counterbalanced by the large contributions for employee pensions and other sources of a surplus by other governmental units. ${ }^{47}$ Net foreign investment is a relatively trivial element fluctuating about zero.

The data on the saving rate for the private sector is potentially distorted

44. An offsetting influence is introduced by treating interest payments by households as an expenditure and deducting them to derive a measure of saving.

45. The difficulties of measuring the transfer of interest among sectors resulted in major changes in the recent revision of the national income accounts.

46. The sharp spike in both saving rates in early 1975 is associated with the large federal tax rebate undertaken in an attempt to end the recession.

47. An argument can be made that those pension contributions should be included in labor compensation as is done with payments in the private sector. Such a change would raise private saving and the total government deficit. 
Figure 4. Sources and Uses of Saving as Percentages of Gross National Product, 1946-81

\section{Percent}
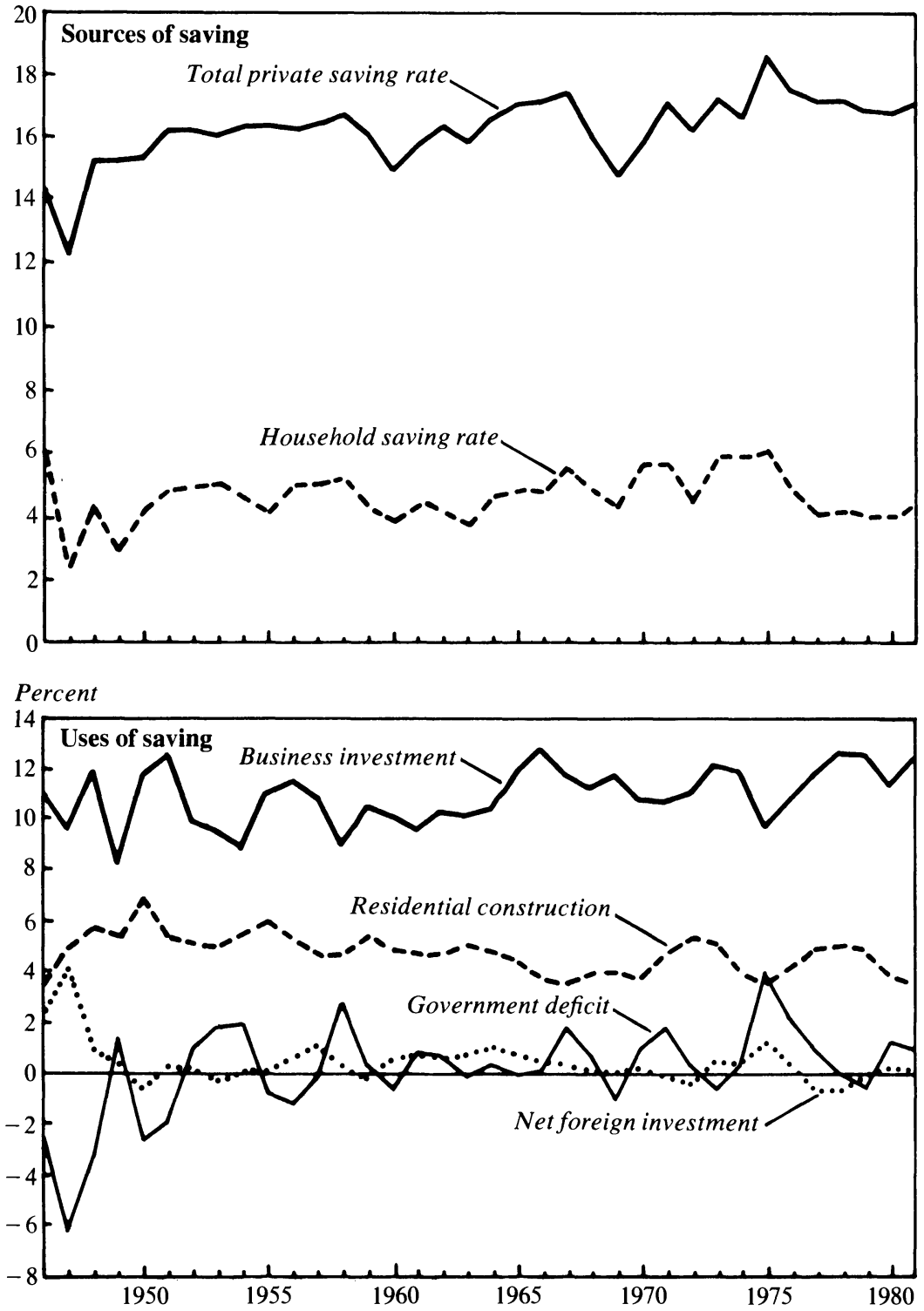

Source: National income and product accounts.

a. Private saving includes household saving, business retained earnings, capital-consumption allowances, and the statistical discrepancy. Business investment is nonresidential fixed investment plus inventory accumulation. Net foreign investment includes capital grants. Note that the government deficit is measured as a positive use of funds. 
by the large flow of net interest payments between the government and that sector. It might be desirable for some purposes to remove from private income and saving the component of those payments that is really attributable to a repayment of principal. Yet no good means of distinguishing between real and nominal interest payments exists. An illustrative calculation can be made by using the actual rate of inflation multiplied by the net outstanding government debt at the beginning of the period. That income flow rises from 0.8 percent of GNP in 1960 to 1.5 percent in 1970 and 2.6 percent in 1980 . If this adjustment had been made in computing the saving ratios, the private saving rate would decline slightly over time, and it would be offset by a small positive saving rate for government.

These data do not support the notion that the rise in effective tax rates has diminished either private saving or business investment. Furthermore, in the one area in which we believe that the combination of inflation and the tax system should promote investment-housing-the proportion of the nation's resources actually used has been declining over the 1970s despite rapid expansion in those demographic groups with the highest demand.

\section{Interpreting the 1970s}

The usual interpretation of events during the 1970s revolves around the notion that inflation induced an increase in the effective tax rate on capital, increased the required before-tax rate of return, lowered the growth of capital relative to output, and through those mechanisms contributed to the slowdown of productivity growth. The data conflict with this story in several respects. Investment has not declined as a share of output even though such a decline would be expected simply because of the slower growth of output during the $1970 \mathrm{~s} .{ }^{48}$ The beforetax return on capital has fallen, and the after-tax return has declined

48. Some investigators have argued that they can detect a slowdown in the ratio of net investment (minus depreciation) to GNP. Because that conclusion is heavily influenced by the rise in depreciation associated with the shift toward less durable assets, such a calculation should have been based on net national product. On that basis I regressed the net investment share on the previous three years of real output growth for 1951-69 and projected the equation through 1970-80. The actual share was above the predicted level in every year except 1978 and 1979. 
even more. Yet that decline in the return on capital has not translated into a lower rate of saving and investment.

One can make more sense of these developments by dropping the assumption of a full employment equilibrium that underlies so much of the policy analysis of recent years and the associated view that inflation is simply a monetary phenomenon reflecting excess aggregate demand. In the presence of idle resources, a rise in inflation (as a result of nonmonetary forces) might be correctly perceived initially by investors as implying a lower real rate of interest on financial assets. Because consumer durables depreciate rapidly and cannot be readily converted to nominal assets for purposes of general consumption, business capital will be the dominant alternative to financial assets. The fall in real rates of interest, therefore, leads to an expansion of business investment at expected future rates of output growth, an exploitation of more marginal projects, a rise in the ratio of tangible capital to output, a decline in the marginal productivity of capital, and a fall in the average rate of return. As long as there is some interest elasticity in the demand for money and the aggregate supply schedule is not vertical, the fall in the return on real assets frustrates the effort of savers to obtain a yield that compensates them for inflation and results in a much smaller equilibrium rise in nominal interest rates than anticipated from the Fisher effect.

The process is even simpler if monetary policy is basically accommodative, as it was throughout the 1970s, in financing the inflation and thereby in preventing a full compensatory rise in nominal interest rates. The monetary policy need not result in excess aggregate demand pressures if fiscal policy and various disruptive events in the world economy introduce negative Keynesian income effects that limit the growth in demand. The sharp rise in the current account surplus of OPEC countries did create just such negative effects on demand by raising world saving. Unless the rest of the world had as its objective a higher overall growth rate, the rise in saving by the OPEC countries required a fall in the real rate of interest to achieve a matching increase in investment. Thus at the level of the world economy the story is the reverse of that being argued by some economists about the United States-intended saving rates increased.

The rigidity of short-term wage and price adjustments required an even more accommodative monetary policy and a larger decline in the real rate of interest to put the surge of world saving to work if employment 
was to be maintained. Such a course for policy, however, would have had a high cost in terms of more inflation. To some extent such a policy was pursued in the United States between 1975 and 1979; but most other countries were less expansive and accepted lower rates of investment and economic growth. ${ }^{49}$

The decade of the 1970s was by no means a good period for capital formation. It was a time of frequent recessions and enormous underutilization of capital. One would have expected a decline in the investment share from that disappointing economic performance alone; yet it did not occur. Investment held up surprisingly well apparently because the effects of inflation in reducing the real cost of capital dominated its effects in raising effective tax rates.

The whole story has changed completely in recent years as monetary policy has become much more restrictive and real rates of interest have soared. The result should be a substantial weakening of investment incentives, both from the direct effect of high real interest rates and from the recession they induced. Martin Baily has argued that the capital stock has become obsolete at an increasing rate. I am somewhat more concerned that it is rotting from lack of use.

\section{Economic Policy and Capital Formation}

The perception that the 1970s was a decade of deficient capital formation has been, in part, the basis for the adoption of an economic policy to stimulate increased rates of investment in the future. But such an argument is not the only reason for advocating an increased emphasis on capital formation in the future. Certainly the rapid growth of the labor force during the 1970s was not matched by a similar expansion of the capital stock; and although the decline in productivity made it possible to absorb those workers with only a small growth of output, a return to higher rates of output growth in the future, if it occurred, would intensify concerns about shortages, the adequacy of industrial capacity, and their potential implications for inflation. It is also not necessary to associate

49. The adjustment problems brought about by the petroleum price increases were discussed in George L. Perry, "The United States," in Edward R. Fried and Charles L. Schultze, eds., Higher Oil Prices and the World Economy: The Adjustment Problem (Brookings Institution, 1975), pp. 71-104. 
the past productivity slowdown with capital in order to advocate more capital as a policy action to offset the negative effects of other factors. ${ }^{50}$ Furthermore, if there is anything to the previous argument that an inflation-induced decline in real interest rates held up investment during the 1970s, a return to lower inflation in future years will exert strong downward pressure on capital formation. ${ }^{51}$ Finally, the emphasis on environmental and other social regulations during the 1970s has undoubtedly led to some diversion of new capital and a premature obsolescence of some existing facilities.

The potential benefits of a higher rate of capital formation, however, should be kept in perspective-particularly benefits accompanying productivity growth. The net investment share of net business output, shown in table 1, has averaged about 4 percent since 1950. Suppose that share was increased by 1 percentage point (a one-fourth increase). At 1981 output levels, that would provide $\$ 20$ billion of additional capital. If this capital earned the postwar average return of 10 percent, national income would rise by $\$ 2$ billion annually, a cumulative gain that would grow over time. It would raise the growth rate of net output by 0.1 percentage point. An increase of 10 percentage points (from 4 to 14 percent) in the net investment share would be necessary to raise the growth rate of output by 1 percentage point annually. The gains would be correspondingly reduced if capital earned the 8 percent rate estimated to apply at full utilization in 1981 rather than its postwar average of 10 percent. The point is not that the gains are not worthwhile, but rather that dramatic changes in investment would be required to have a major effect on productivity growth.

\section{CURRENT POLICY}

The objective of increasing the share of the nation's output devoted to business capital formation is a major rationale for the current economic

50. Obviously if the return on capital falls rapidly in response to capital deepening, as it appears to have done during the 1970s, the policy may have limited returns.

51. In fact, although the rise in effective tax rates is associated largely with the failure to index taxable capital income for inflation, the policy response has ignored that aspect of the problem and emphasized changes in other features of the tax system, such as exclusion of large portions of capital income from the tax base, reductions in rates, and a shortening of asset lifetimes for tax purposes. As a result the effective tax rate continues to be sensitive to inflation, and a return to low inflation could result in very low, if not negative, taxation of income from some assets. 
policy. The major features of that policy would seem to be tax incentives to promote private saving and a combination of monetary restraint and investment tax incentives to shift the composition of investment. ${ }^{52}$ Monetary restraint reduces all forms of investment, including consumer durables and home building, while the tax incentives are aimed at more than offsetting those effects on business investment. Such a program is sharply at odds with the traditional prescription that the investment share of output is increased by a combination of a tight fiscal policy (reduced consumption) and easy money (increased investment).

The evaluation of the program depends on the answer to several controversial questions. The empirical issue of the sensitivity of saving decisions to rates of return has been extensively discussed before, albeit without a resolution. ${ }^{53}$ Three other issues have received less attention. First, will the personal tax reductions result in a net increase in the amount of saving available for capital formation? Second, what are the implications of a program aimed at shifting the allocation of total investment from households to business as opposed to an emphasis on a shift of output from consumption to investment as a whole? Third, is it reasonable to view saving as the constraining influence on domestic business investment in the sense that an incremental increase in planned saving will be channeled into business investment?

Fiscal Policy and National Saving. The 1981 personal tax reduction was promoted as a way of increasing the volume of total saving available for private capital investment. As stated earlier, there is little agreement about the effect of the tax changes on private saving. But independent of that issue, an increase in private saving does not imply a rise in resources for investment unless government expenditures decline in line with the tax cut so that any rise in private saving is not absorbed by higher levels of the federal budget deficit. In the extreme case of no change in the intended path of total expenditures, the private sector must

52. The major features of the program were advocated several years ago in Martin Feldstein, "Tax Rules and the Mismanagement of Monetary Policy," American Economic Review, vol. 70 (May 1980, Papers and Proceedings, 1979), pp. 182-86.

53. A useful survey is provided in the Organization for Economic Cooperation and Development, "International Differences and Trend Changes in Saving Rates," note by the Secretariat for Working Party 1 of the Economic Policy Committee, CPE/WP1(81)9 (Paris: October 1981). Major U.S. contributions on opposite sides of the issue are E. Philip Howrey and Saul H. Hymans, "The Measurement and Determination of Loanable-Funds Saving," BPEA, 3:1978, pp. 655-85; and Michael J. Boskin, "Taxation, Saving, and the Rate of Interest,' Journal of Political Economy, vol. 86 (April 1978), pt. 2, pp. S3-S27. 
save the entire tax cut in order simply to leave the saving-investment balance unchanged. Alternatively, if government expenditures decline in step with taxes-a fiscal change that leaves the high employment surplus unchanged-any addition to private saving coming from the tax cut is potentially available for private investment.

In fact, the administration proposed and Congress passed the major tax cut in 1981 without any consensus on how they could achieve an offsetting reduction in expenditures. As a result, the fiscal change added enormously to the high employment deficit. At the same time, a variety of factors-most important, a restrictive monetary policy-greatly reduced economic activity and contributed to a large further rise in the actual budget deficit.

The high employment budget deficit averaged 0.4 percent of GNP in the four-year period between 1978 and $1981 .{ }^{54}$ The recent review of the budget outlook by the Congressional Budget Office projects that full enactment of the tax reduction and adherence to the current budget resolution will raise the high employment deficit by about one percentage point by 1985.55 The tax reduction enacted in 1981 added about 3 percent of GNP to this deficit. Thus other budget actions will finance about twothirds of the tax cut, and the private sector will have to save at least onethird of the tax cut simply to hold constant the share of domestic saving available for private capital formation. Very large increases in private saving would have to be forthcoming to produce a significant net increase in the national saving rate anytime in the near future.

In contrast to the budget strategy that has been adopted, and in view of the uncertainties surrounding the effect of taxes on private saving decisions and the difficulties of achieving expenditure reductions in step with the decline in tax revenues, conventional prescriptions have viewed

54. That particular choice of a standardized level of output growth has little effect on the calculations of the change in the budget balance. I have used the high employment growth path to calculate the high-employment budget receipts and expenditures as published in U.S. Bureau of Economic Analysis, Survey of Current Business, vol. 62 (April 1982), pp. 21-33, which assumes a standardized unemployment rate of 5.1 percent.

55. Congressional Budget Office, The Economic and Budget Outlook: An Update (Government Printing Office, September 1982), p. 36. Because the 1982 tax increase was less than that targeted in the first concurrent budget resolution and Congress has not been able to achieve in actual decisions the expenditure reductions targeted in that resolution, the above estimate of the change in the deficit is probably low. Furthermore, the administration has refused to accept the reduced target for defense spending. 
a shift toward government budget surpluses as a more certain means of increasing national saving rates.

Shifts in the Investment Mix. One rationale for the particular mix of current economic policy is that it aims to increase the flow of resources into private business investment by a drastic shift in the mix of output among those components of demand that are sensitive to interest rates. Monetary restraint raises real interest rates, thereby reducing consumer durable spending, residential construction, and business investment; but specific tax incentives for investment in business plant and equipment are intended to offset the higher cost of funds for that sector. Thus, although total saving and investment might be reduced, the combination of higher interest rates and the targeted investment incentives could shift the composition of total investment toward business capital. ${ }^{56}$

Two major objections to the policy focus on the distribution of the burden of reduced expenditures in areas such as home building and the tradable goods sectors of the economy.

The extent to which higher business investment should be financed by lower rates of home building ultimately revolves around conflicting views of national priorities. Those advocating a shift of resources away from home building usually argue that inflation-induced changes in the tax rate lead to an excessive expansion of home building. It is not clear, however, that the United States has actually built up a surplus housing stock. As discussed above, residential construction accounted for 4.2 percent of real GNP in 1971-80 compared to an average of 4.5 percent in the previous two decades. A large part of the discussion about the supposed overinvestment in owner-occupied housing has ignored the fact that much of that investment was simply a shift between owneroccupied and rental units. Many families have been constrained from taking advantage of the tax benefits by the magnitude of the monthly payments associated with high nominal interest rates; and, apart from cyclical fluctuations, the supply has been very price-inelastic. ${ }^{57}$ Much of the so-called housing boom was reflected in higher prices of land and

56. This is the policy mechanism emphasized in Feldstein, "Tax Rules and the Mismanagement of Monetary Policy."

57. In effect, high nominal rates have required a much faster repayment of the principal than what would be required in a noninflationary world. Current homeowners are also, to an increasing extent, requiring new owners to pay early for all the incremental costs to the local government through highly restrictive local zoning ordinances. 
existing houses rather than additions to the real stock of housing. ${ }^{58}$ Given the size of the home-building industry and the rapid growth in the number of households during the 1980s, a significant shift of resources from that sector into other uses will be difficult and controversial.

A second major objection to current economic policy is that the rise in the real rate of interest in the United States induces a flow of capital into the United States and an appreciation of the exchange rate. As a result the rise in domestic investment is financed, in part, through the foreign sector by reduced exports and increased imports. The burden of the adjustment (in the form of reduced production and employment) will fall heavily on industries with significant foreign competition. Initially the new investment also will be steered away from those industries because of the depressed state of their markets.

The advocates of any such shift in the policy mix must envision a set of investment tax incentives sufficient to offset not only the direct effects of higher interest rates on investment but also the indirect effects of monetary policy restraint. These operate through other channels, such as home building, foreign trade, and consumer durables, and lead to a lower level of total demand that reduces business perceptions about the need for additional capital. The situation is worsened by the outlook for substantially higher government deficits, which will also contribute to higher real interest rates when combined with an unyielding monetary policy. These disincentives to invest appear to be greater than can be overcome by any feasible set of investment tax incentives.

The rise in real interest rates since 1980 , for example, has more than offset the 1981 investment tax incentives and, on net balance, the outlook for domestic investment has worsened even without taking account of the effects of the recession. The calculations shown in table 5 indicate that the required before-tax rate of return has been substantially increased for assets of all durabilities by the combined effects of higher interest rates and tax reductions. The estimates are based on 100 percent debt financing, but they are conservative because they do not incorporate any reduction in inflation expectations, so that the rise in real interest rates is limited to an increase of 3.5 percentage points in the nominal

58. This does create the possibility that rising home values increased household wealth and lowered saving through the stimulus to consumption. On the other hand, during the 1970 s the gains in wealth from rising house values were more than offset by declines in the real value of corporate stock. 
Table 5. Effects on the Required Rate of Return on Corporate Investment of the Accelerated Cost Recovery System and Changes in Market Interest Rates

Percentage point change

\begin{tabular}{lccc}
\hline & $\begin{array}{c}\text { Effect of } \\
\text { higher } \\
\text { interest rate } \\
(1980 \text { law) }\end{array}$ & $\begin{array}{c}\text { Effect of } \\
\text { accelerated } \\
\text { cost recovery } \\
\text { (198I in- } \\
\text { terest rate })\end{array}$ & $\begin{array}{c}\text { Combined } \\
\text { effect }\end{array}$ \\
\hline \multicolumn{1}{c}{ Type of asset } & & & \\
$\quad$ Thuipment & 2.6 & -1.6 & 1.0 \\
Five years & 2.6 & -1.0 & 1.6 \\
Ten years & 2.4 & -0.4 & 2.0 \\
$\quad$ Twenty years (nonutility) & 2.5 & -1.1 & 1.4 \\
Structures & & & \\
$\quad$ Residential & & -0.6 & 4.0 \\
$\quad$ Nonresidential & 3.6 & -1.1 & 2.3 \\
\hline
\end{tabular}

Source: Author's calculations based on the following: $T$, corporate tax rate $(0.46)$; $\delta$, economic rate of depreciation ( 1.25 divided by the midpoint of the asset depreciation range); $\pi$, expected inflation ( 7 percent); $i$, pretax yield, corporate AAA new issue (11.4 percent for 1980 and 15.0 percent for 1981): $r$, real after-tax rate $=i(1-T)-\pi$; $f$, present value of depreciation deductions and credits, discounted at $i(1-T)$, for before and after the 1981 tax law: $c$, rental price of capital $=(r+\delta)(1-T f) /(1-T)$; and $p$, pretax rate of return $=c-\delta$.

interest rate. This decline in investment incentives exists despite the fact that the accelerated cost-recovery system essentially. wipes out the corporate tax for a wide range of new assets and implies tax subsidies for others. ${ }^{59}$

Although a program of monetary restraint combined with tax incentives for investment might provide a stimulus to investment in theory, the practical application calls for pursuing such incentives to the point that many elements of investment are subsidized by the tax system. The rise in interest rates required by this policy mix also frustrates the transfer of any increment to private saving induced by the personal tax measures because the transfer requires a decline in real rates and a high interest elasticity of business investment relative to other interestsensitive outlays-the reverse precondition for an effective stimulus from a monetary restraint-investment tax reduction program.

\section{SAVING AND INVESTMENT IN THE LONGER RUN}

Quite apart from whether the fiscal program will raise the national saving rate in the short run, there is a basic long-term question of whether

59. Alan Auerbach, "The New Economics of Accelerated Depreciation," Boston College Law Review (forthcoming). 
a rise in planned saving rates, if it could be engineered, would translate into increased domestic investment. In other words, is it reasonable to view domestic saving as a constraint on private domestic investment, and is the current focus on incentives to save responsive to the need for more capital formation? In an idealized world of full employment, flexible wages and prices, and no international capital flows, a distinction between saving and investment incentives would be irrelevant because capital markets would ensure a smooth transfer of resources from saving to investment. But in reality there can be many slips betwixt and between.

For example, if prices or wages are not fully flexible, an increase in planned saving, because it implies less consumption, may initially reduce aggregate demand, production, and perceptions by the business sector of its future capital needs. The resulting ex post balance is one of less output and a decrease in investment and saving. The dominance of this Keynesian income effect in the short run implies that incentives to save must be combined with simultaneous actions to expand investment.

The previous discussion of increased government deficits is only one possible leakage in the flow from private saving to private investment. The linkages of international capital markets would, in the extreme case of perfect capital markets, imply an equalization of rates of return on capital among countries, and there will be no necessary relation between domestic investment and domestic saving. ${ }^{60}$ Low levels of domestic saving would not preclude the exploitation of profitable domestic investment opportunities, and efforts to stimulate domestic saving would simply lead to increased capital outflows.

While many investigators would accept the view that in the short run there are barriers to the free movement of capital among countries, it is the short run in which the Keynesian income effects are most important. In the long run the income effects may be of less concern, but it is more difficult to argue that capital will not flow to the country where the returns are greatest.

The role of international capital flows has been examined in two

60. There is a welfare argument for reduced taxation of the income from saving that is based upon the distorting effects of such taxes on the rate of substitution between current and future consumption. The magnitude of the welfare loss compared to taxation of labor income depends upon the relative price elasticities of saving and labor supply decisions. Such an argument is unrelated to the issue of domestic rates of capital formation. In fact, as long as the focus is on maximizing the present value of national income, such saving should flow abroad if that is where the return on capital is highest. 
papers by Feldstein and by Horioka and Feldstein. ${ }^{61}$ Both papers used data on saving and investment shares among the OECD countries averaged over 1960-79, and they defined domestic saving and investment as including the government sector, so that the residual difference was net foreign investment minus the statistical discrepancy. They estimated - for a sample of seventeen countries an equation of the form

$$
I / Y=a+b S / Y .
$$

Because the $b$ coefficient was close to unity $(0.8-1.0)$, they argued that sustained increases in domestic saving induce approximately equal increases in domestic investment.

But this procedure cannot measure the extent to which an increment to domestic saving may flow abroad. A major problem comes from spurious correlation from common third factors. It is most evident in time-series data in which common business cycle influences create a close correlation between saving and domestic investment. A previous study of international differences in saving rates by Feldstein found that differences in the growth of gross domestic product (GDP) was the largest single contributor to differences in saving rates and that such differences can persist over several decades. ${ }^{62}$ At the same time, the growth of GDP has a powerful influence on investment. That common influence is present for both time-series and cross-sectional data; the averaging of annual observations does not remove it. ${ }^{63}$

The international data also have severe measurement problems. The United States obtains somewhat different estimates of investment and saving than other countries because it measures GDP by two methods: an aggregation of final demand expenditures and an aggregation of factorincome payments. The income data is necessary to obtain an estimate of saving independent of the estimate of investment. But most other countries do not have an income estimate of GDP. They use instead the

61. Martin Feldstein and Charles Horioka, "Domestic Saving and International Capital Flows," Economic Journal, vol. 90 (June 1980), pp. 314-29; and Martin Feldstein, "Domestic Saving and International Capital Movements in the Long-Run and the ShortRun," paper presented at the National Bureau of Economic Research Conference, Fifth Annual International Seminar on Macroeconomics (University of Mannheim, Germany, June 1982).

62. Martin Feldstein, "International Differences in Social Security and Saving," Journal of Public Economics, vol. 14 (October 1980), pp. 225-44.

63. Feldstein's study shows that annual observations and changes in that data also yielded results very similar to those for data averaged over periods as long as nineteen years. 
expenditure method plus an aggregation of industry information on production-the output method. In fact, many countries do not have an estimate of total expenditures and use the difference between GDP obtained by the output method and the aggregation of expenditures as an estimate of the change in inventory stocks, a component of investment-resulting in no reported statistical discrepancy.

For most countries an estimate of national saving is derived by adding investment and current account surplus (or net foreign investment, NFI) of the balance of payments. Thus any error in estimating foreign or domestic investment is directly reflected in the measure of saving.

Feldstein and Horioka may have estimated an identity for which the expected value of the $b$ coefficient is unity regardless of one's view of the causal relation. The identity is

$$
I / Y=a+b S / Y-c N F I / Y,
$$

where the expected value of $b$ and $c$ are both unity by definition. In their estimated model, the $c N F I / Y$ term was excluded. The relevant statistical issue becomes the bias introduced by the potential correlation of saving and net foreign investment. Variations in GDP growth and the measurement error of national accounts both will insure a correlation between domestic investment and saving, and it is also true that any error in measuring net foreign investment will be positively correlated with domestic saving for most countries. These factors argue for a strong positive correlation even in the absence of a causal relation.

On the other hand, any behavioral correlation between domestic investment and net foreign investment is reflected in a negative correlation of domestic investment with the measure of domestic saving, which ensures an estimated value of $b$ less than unity. ${ }^{64}$ Studies by Sachs and von Furstenberg found that about half of domestic investment changes were financed by such compensatory changes in net foreign investment ${ }^{65}$

64. Feldstein does address some of the estimation problems that result when domestic income is excluded from the behavioral functions for investment and saving, and the measurement problems are not discussed.

65. Jeffrey D. Sachs, "The Current Account and Macroeconomic Adjustment in the 1970s," BPEA, 1:1981, pp. 201-68 and George M. Von Furstenberg, "Domestic Determinants of Net U.S. Foreign Investment," International Monetary Fund Staff Papers, vol. 27 (December 1980), pp. 637-78. Von Furstenberg argues that as much as 80 percent of the variation in net foreign investment is explainable by domestic factors. The study by 
As a result of these statistical concerns it is difficult to attach much meaning to the results of Feldstein and Horioka. In any case, most reforms of the 1970s have had as their objective the reduction of barriers to the international flow of capital, and evidence on capital flows from previous decades may be irrelevant to today's situation. Although Feldstein and Horioka are certainly correct to point out that international capital flows are not unrestricted, the evidence from the studies of Sachs and von Furstenberg argues for a middle ground in which such capital flows do constitute a significant leakage in the relation between marginal changes in domestic saving and domestic investment.

\section{CONCLUSIONS}

The above analysis reinforces the earlier conclusion that increased saving cannot be relied upon to increase domestic capital formation. While the previous sections stressed the short-term effects of increased saving, the behavior of capital flows in an open economy suggests that domestic saving should not be viewed as a major constraint on domestic investment over the longer term. A program to expand domestic capital formation requires attention to all aspects of the saving-investment decision, including expectations of future growth in demand, interest rates, and tax policy. And it requires an integrated policy that takes account of both sides of the saving-investment relation.

Currently capital formation has joined the unemployed as a victim of the recession. The failure to coordinate fiscal and monetary policies has led to a deterioration rather than an improvement in investment incentives that is likely to continue for many years. It is extremely difficult to develop an effective program to raise capital formation when monetary policy is committed to an "all-out" attack on inflation and fiscal policy is caught up in an ideological debate over the appropriate size of the public sector.

Sachs focuses on the relation between domestic investment and net foreign investment. Because the two data series are obtained from separate accounting systems, they should be free of any correlation from measurement errors alone. 


\section{Comments and Discussion}

Robert M. Solow: This paper by Barry Bosworth is about nearly everything having to do with capital formation. I have to admit it is an interesting paper, though, with a lot of good ideas, even if it raises more questions than it can answer.

The first thing Bosworth does is to review the bidding on the deterioration of productivity growth in the 1970s. His main conclusion is that very little of the shortfall in productivity growth can be attributed to weak capital investment. He is almost certainly right about that, but I do not think it is a surprise any more. A year or so ago William Nordhaus did a reevaluation of the productivity slowdown that tried to come to a best-guess common-sense evaluation of the whole picture. He concluded that if the productivity deceleration amounted to a little over 2 percent a year, cyclically adjusted, then one could not blame the capital factor for more than, say, three-tenths of a percent of that. Bosworth comes out in the same ball park, although he is using slightly different data, and I do not see how anyone could argue strongly to the contrary.

In the course of doing this reevaluation, however, Bosworth comes up with a number of new and interesting observations. The last time I was a discussant at these meetings I talked about Martin Baily's paper on the hypothesis that big relative price changes and other adverse developments could have reduced the flow of services from the current stock of capital. Anyway, I was curious about what Bosworth would have to say about that hypothesis. He put together a number of bits of evidence, but in the end he is not very positive on the Baily hypothesis. I am not sure he interprets the shift data correctly, but I thought the most impressive of Bosworth's findings was that a regression of reported capacity in manufacturing on time and the gross capital stock underpre- 
dicts actual capacity more and more after 1970 . By 1980 the gap is almost 25 percent of reported capacity, though that is an upper limit if you make some allowance for the share of pollution-control equipment. That is pretty favorable to Baily. It is true that the gap begins to open in 196970, a bit early for Baily's reasoning, but it clearly accelerates after 1974, which is just right for Baily's reasoning.

There is a problem of interpretation, though. In principle, the gap Bosworth measures is in units of output or capacity, so even if the gap is written down to perhaps 15 percent to allow for the environmental factors, a loss of that much capacity over a decade is impressive. However, Bosworth's regression for predicted capacity amounts precisely to a time-trend times the gross stock of capital. It seems to me that interpreting the regression to measure the capacity to produce output is inconsistent with the usual small elasticity, or at least requires a more sophisticated model than a simple production function in capital and labor. If it really measures effective capital rather than capacity, by the time one converts it to units of output via the usual small elasticity, there will not be much left beyond the usual few tenths of a percent a year.

Another new item in the paper is Bosworth's emphasis on the rise in the capital-output ratio, cyclically adjusted, from 1970 to 1980 . The rise is not tremendous, but it appears to be there. There is the least bit of cause for suspicion about Bosworth's cyclical adjustment because his unadjusted series for the rate of return on capital shows a substantial dip in 1974-75, as one would expect, which is somehow converted into an even sharper spike in 1975 after cyclical adjustment. One of my gripes is that everybody in this business rolls their own cyclical adjustment method with every paper. I wish we could somehow standardize on one and use it consistently. Nevertheless, the conjunction of rising capitaloutput ratio and falling rate of return on capital plays an important role in Bosworth's interpretation of what has been going on since 1970, so I will dwell on it for a while.

For one thing, given changes in the capital-output ratio and the rate of return (both cyclically adjusted, of course) it is natural to ask what elasticity of substitution they imply. In Bosworth's calculations, there is a drop of 27 percent in the rate of return between 1967 and 1980 and an increase of 11 percent in the capital-output ratio during the same period. That figures out to an elasticity of substitution of 0.4 to 0.5 , which 
is a little small but not outlandish. It is peculiar that a lot of the action in the numbers occurs in the noncorporate nonfarm sector, where the measurement of the return to capital is pretty dodgy. If attention is limited to nonfinancial corporations, the fall in the rate of return is somewhat smaller and the rise in the capital-output ratio much smaller, so the implied elasticity of substitution must be considerably less than 0.4 and that does not sound too good. But he thinks the larger aggregate is the more sensible one to consider, and as a general proposition I think he is right.

There is another puzzle here. Bosworth proposes to interpret the conjunction of rising capital-output ratio and falling rate of return as a more or less classical deepening of capital. The puzzle resides in the fact that the capital-labor ratio was almost flat in the second half of the 1970s and probably did not rise much between 1967 and 1980. If there is any technological progress at all, a constant capital-labor ratio would imply a falling capital-output ratio, so I take it that even a small rise in the capital-labor ratio would be hard to reconcile with the perceptible rise in the capital-output ratio. I tried to see if biased technical progress might do the trick, but the required conjunction seems impossible or difficult to rationalize that way.

Nevertheless, the facts are there. The rest of Bosworth's story is less classical in one respect. He suggests that the deepening of capital in the 1970s was a response to a reduction in the real cost of funds, which in turn happened because nominal interest rates failed to keep pace with inflation. That certainly changed toward the end of the decade. Stick around, and we will see what happens if real interest rates stay high for a few more years.

Bosworth does not believe the more usual story that the nonneutrality of the tax system with respect to inflation caused an erosion of the aftertax return to capital and therefore a disincentive to invest. He argues pretty convincingly that (1) in that story, business ought to have taken steps to increase the before-tax rate of return, but that did not happen; and that (2) business fixed investment has been fairly strong in the 1970s, all things considered. One could say, in reply to (1), that the state of business during most of the 1970s was not exactly what the doctor ordered for shifting higher effective taxes back onto customers. But point 2 presents difficulty for those who accept the story about inflation, taxation, and investment. They can point to the capital-labor ratio, but then we are back to square one. Bosworth has some rather critical things 
to say about the substance of the tax story, by the way. The pros and cons are hard to judge, but he makes a strong case.

For sure, Bosworth is pretty devastating on the administration's line that it is going to solve problems by providing incentives to save. In the first place, private saving has actually held up pretty well, too. In the second place, most of the so-called incentives to save do not have much effect on saving. And in the third place, any pickup in investment would generate its own savings through the multiplier process, given how far below its potential the economy stands these days. Of course, I have always felt that all that talk about incentives was just a cover story for the Reagan administration's real goal, which was regressive redistribution of income, pure and simple.

Lawrence H. Summers: Barry Bosworth's paper presents a thoughtful discussion of a number of issues connected with the linkages between economic policy and capital formation. While Bosworth writes in a cautious, balanced way, over the course of the paper his views become clear. He is evidently skeptical about the case for more capital formation and dubious about the potential efficacy of the policy mix currently being pursued. In my comments, I concentrate on the parts of Bosworth's analysis and conclusions with which I disagree.

Performance of capital formation during the 1970s relative to earlier periods by now has been discussed in a number of places. I am not sure what hangs on the question of whether the rate of investment was higher or lower than postwar norms during the 1970s. Net fixed nonresidential investment has been viewed as inadequate during much of the postwar period. For example, the investment tax credit (ITC) was enacted in 1962 and subsequently increased several times because of a widespread conviction that rapid economic growth required an increase in the share of national output devoted to investment. Before the initial enactment of the ITC, the rate of net investment as a fraction of GNP was lower than it was during the 1970s.

The argument of those concerned about the effects of a nonindexed tax system during the 1970s was never that investment reached some unprecedented low. Rather, it was that inflation had eroded the stimulus provided by the introduction of the ITC and the acceleration of depreciation and so we had returned to the unsatisfactory situation that prevailed before these measures were introduced.

Bosworth presents a careful analysis suggesting that capital services 
during 1973-80 grew at roughly the same rate as during 1948-67 and somewhat more slowly than during 1967-73. Although the 1967-73 interval may now appear to be an aberrant period, this does not mean that the rate of capital formation then achieved is not a plausible goal. Given the acceleration of growth of the labor force and new investment opportunities in production and conservation brought about by a fourfold increase in the price of oil and the accelerated obsolescence of at least some capital, an omniscient central planner would almost certainly have sought an increased rather than a decreased growth rate of capital services during the 1970s. The capital formation problem during the 1970s arose because capital formation returned to levels that have long been regarded as inadequate despite the increased need for capital.

I agree with Bosworth that slower capital accumulation did not cause a large part of the productivity slowdown and that more investment will not, by itself, be enough to reverse it. Even here, let me record one doubt. After a great deal of study, economists still attribute a large part of productivity differences over time to an unexplained residual. One cannot help being struck by the strong positive correlation internationally between savings and productivity growth rates. Perhaps there are channels linking capital formation and productivity growth that are not yet understood. These might include the spillover effects of R\&D done by capital goods producers, learning by doing, or the effects of new capital goods on worker morale and management techniques.

In my view the more important argument for increased capital accumulation rests on a comparison of the social discount rate and the pretax marginal return on investment. The latter figure is probably about 10 percent per year; the former is a value judgment. If the social discount rate is less than 10 percent, we should be investing more. Since an investment earning 10 percent per year compounds to more than ten times its initial value in a generation, there is a case for increased capital accumulation as long as we give the next generation's consumption more than one-tenth the weight we give our own.

Bosworth properly emphasizes a crucial question. Why, in a decade of low capacity utilization, high energy prices, apparently low returns to capital, and allegedly substantially increased tax burdens, was investment performance as good as it was? Let me first dismiss what I think is a bad answer. Many people have noted that in inflationary periods, real interest rates and a fortiori real after-tax interest rates tend to fall. This, 
it is suggested, could lead to increases in investment. I share the view forcefully expressed by James Tobin, William Brainard, and others that the real interest rate is a poor measure of the cost of capital. The vast majority of investment is equity financed, and the cost of this source of capital rose precipitously during the recent interval. Earnings price ratios rose from the 5 to 6 percent range that prevailed during the 1960s to double-digit levels in the late 1970s. Another good indicator of the cost of capital is the variable $Z$ developed by Brainard, John Shoven, and Laurence Weiss, which takes into account both debt and equity finance and which rose sharply during the 1970 s.

Of course, all this only deepens the problem of why there was so much investment during the 1970s. I believe a large part of the answer must lie in the distinction between marginal and average $Q$ and in the sort of accelerated obsolescence effects stressed by Martin Baily in connection with the productivity slowdown. The explanation of the productivity slowdown I leave to others. However, I think the view that capital is heterogenous and specialized fits a number of facts about the behavior of investment. The change in relative prices caused by the energy shock meant that many investments had high marginal $Q$ even with low average $Q$. A great deal of capital became only marginally profitable. This decline raised the marginal return on new investment. If one goes even a small way toward accepting Baily's idea that the market value of a firm measures the quantity of capital it has, the marginal productivity of investment actually rose quite a bit between the 1960s and the 1970s.

This observation has an important implication. Unless one expects another decade with events like the 1970s, the marginal product of new investment is going to be much greater than the average return on all capital. I do not think that any of the evidence Bosworth cites really goes against this hypothesis. And at least the airline industry fits it. Bosworth's evidence on scrappage is inconclusive and, in any case, is not inconsistent with the hypothesis. As for shares, the consequence of the destruction of some capital could be a more intense use of other capital.

Finally, there is the question of policy mix. Bosworth's characterization of policy during the past few years reminds me of the anonymous colonel who claimed that he "destroyed a village in order to save it." At the outset it is important to recognize that an increased level of investment 
is only one of the objectives of the current policy mix. It is within the constraints that policy must be directed at long-term reductions in the size of the public sector and in light of the rate of inflation that the current policy package directed at increasing investment must be appraised. It is not a policy that is directed solely at increasing investment in the short run. Nor should it ever have been claimed that the short-run consequence of rapid disinflation would be anything other than a sharp decline in capital formation. The evidence on whether the current policy package will succeed in achieving the ultimate objective of sustained noninflationary growth is not yet in.

\section{General Discussion}

There was a spirited discussion of the policy implications arising from Bosworth's paper. James Tobin observed that an evaluation of the administration's policy on investment must take into account the monetary as well as the fiscal policies that were planned and pursued. On balance, the policy combination of large deficits and tight money is likely to depress investment for an extended period. Benjamin Friedman noted that the distinction between the cyclical impact of present policies on the level of investment and their longer-run impact on the share of investment in total output was not being made when these policies were being advocated. Congress supported the administration's policies because they had been told they would stimulate actual investment. Peter Kenen observed that many advocates of present policies had stressed the importance of credibility for their success. The unrealistic and now unrealized expectations on which those policies were sold today compound the difficulties faced by the administration in maintaining the credibility of its policies.

Robert J. Gordon interpreted Bosworth's capacity regressions as simply showing that the rate of return to investment was lower in the 1970s than it had been in the 1950s and 1960s. He did not think this was a new finding. He also disagreed with Bosworth's cyclical adjustments to the rate of return. According to Gordon's research, the economy was actually operating below the nonaccelerating inflation rate of unemployment during much of the $1950 \mathrm{~s}$. A cyclically adjusted rate of return that accepted that view would decline far less than Bosworth's estimates. Gordon explained the high profit rate of the 1960s as an indirect effect of 
the wage-price guideposts. In his research, the guideposts dampened wage settlements but not price inflation, thus raising the profit share abnormally during this period.

Roger Gordon believed that, contrary to Bosworth's contention, taxation of capital has declined over the period studied in the paper. He observed that the difference might arise because Bosworth used average tax rates in his calculations, whereas marginal tax rates are relevant to investment incentives. According to Gordon's calculations, capital was slightly subsidized at the margin in 1973 and it is currently heavily subsidized.

Tom Juster pointed out that Bosworth's emphasis on the total national saving rate may be somewhat misleading. He reported that research by Richard and Nancy Ruggles showed that the effect of household saving on capital formation is quite different from the effect of corporate saving. Household saving is used largely for household investment-home buying, consumer durables, and so forth. Corporate saving is used largely for corporate investment-plant, land, and equipment. Therefore policies designed to encourage household saving, such as Individual Retirement Accounts, could not be relied on to increase corporate capital formation. However, Gary Burtless reasoned that since the household sector owns the corporate sector, the pattern of investment should not depend on where the saving occurs.

Kenen congratulated Bosworth for taking account of the foreign sector, which is frequently ignored by macroeconomists. The exchange rate affects investment incentives and may be significant in explaining the investment performance during the past decade. Kenen noted that in recent years the high value of the dollar has probably discouraged investment in the traded goods industries.

Alan Blinder emphatically rejected the notion in Summers's discussion that the stock market could provide a meaningful measure of the stock of physical capital. He observed that stock market prices rose more than 20 percent during a few weeks in the fall of 1982, and found it difficult to argue that this had anything to do with changes in the physical quantity of capital. Martin Baily replied that, although short-term fluctuations in stock values were often meaningless, a depression of stock values lasting several years probably should be interpreted as conveying information about the profitability of the capital stock.

William Fellner speculated on whether government deficits are fi- 
nanced at the expense of private investment. He noted the so-called Ricardian theory that households would take account of the future tax liabilities necessary to finance deficits and consequently adjust their saving to offset them. If this were so, private investment would be unaffected by the deficits. But Fellner doubted the model of household behavior in this theory. While it is likely that savers make allowances for part of the loss in the real value of the government securities they acquire, his analysis so far suggests that deficits very largely come at the expense of investment for any given level of total output. 